\title{
Conversion of tropical forests to smallholder rubber and oil palm plantations impacts nutrient leaching losses and nutrient retention efficiency in highly weathered soils
}

\author{
Syahrul Kurniawan ${ }^{1,3}$, Marife D. Corre ${ }^{1}$, Amanda L. Matson ${ }^{1}$, Hubert Schulte-Bisping ${ }^{2}$, Sri Rahayu Utami ${ }^{3}$, \\ Oliver van Straaten ${ }^{1}$, and Edzo Veldkamp ${ }^{1}$ \\ ${ }^{1}$ Soil Science of Tropical and Subtropical Ecosystems, Faculty of Forest Sciences and Forest Ecology, \\ University of Göttingen, Germany \\ ${ }^{2}$ Soil Science of Temperate Ecosystems, Faculty of Forest Sciences and Forest Ecology, \\ University of Göttingen, Germany \\ ${ }^{3}$ Department of Soil Science, Faculty of Agriculture, Brawijaya University, Indonesia \\ Correspondence: Marife D. Corre (mcorre@gwdg.de)
}

Received: 2 May 2018 - Discussion started: 23 May 2018

Revised: 10 August 2018 - Accepted: 14 August 2018 - Published: 27 August 2018

\begin{abstract}
Conversion of forest to rubber and oil palm plantations is widespread in Sumatra, Indonesia, and it is largely unknown how such land-use conversion affects nutrient leaching losses. Our study aimed to quantify nutrient leaching and nutrient retention efficiency in the soil after land-use conversion to smallholder rubber and oil palm plantations. In Jambi province, Indonesia, we selected two landscapes on highly weathered Acrisol soils that mainly differed in texture: loam and clay. Within each soil type, we compared two reference land uses, lowland forest and jungle rubber (defined as rubber trees interspersed in secondary forest), with two converted land uses: smallholder rubber and oil palm plantations. Within each soil type, the first three land uses were represented by 4 replicate sites and the oil palm by three sites, totaling 30 sites. We measured leaching losses using suction cup lysimeters sampled biweekly to monthly from February to December 2013. Forests and jungle rubber had low solute concentrations in drainage water, suggesting low internal inputs of rock-derived nutrients and efficient internal cycling of nutrients. These reference land uses on the clay Acrisol soils had lower leaching of dissolved $\mathrm{N}$ and base cations $(P=0.01-0.06)$ and higher $\mathrm{N}$ and base cation retention efficiency $(P<0.01-0.07)$ than those on the loam Acrisols. In the converted land uses, particularly on the loam Acrisol, the fertilized area of oil palm plantations showed higher leaching of dissolved $\mathrm{N}$, organic $\mathrm{C}$, and base cations $(P<0.01-0.08)$ and lower $\mathrm{N}$ and base cation retention effi-
\end{abstract}

ciency compared to all the other land uses $(P<0.01-0.06)$. The unfertilized rubber plantations, particularly on the loam Acrisol, showed lower leaching of dissolved $\mathrm{P}(P=0.08)$ and organic $\mathrm{C}(P<0.01)$ compared to forest or jungle rubber, reflecting decreases in soil $\mathrm{P}$ stocks and $\mathrm{C}$ inputs to the soil. Our results suggest that land-use conversion to rubber and oil palm causes disruption of initially efficient nutrient cycling, which decreases nutrient availability. Over time, smallholders will likely be increasingly reliant on fertilization, with the risk of diminishing water quality due to increased nutrient leaching. Thus, there is a need to develop management practices to minimize leaching while sustaining productivity.

\section{Introduction}

Rainforests play an important role in maintaining groundwater quality in tropical regions; however, in some regions their effectiveness may be decreasing as a consequence of forest conversion to agriculture. From 1990 to 2010, the deforestation rate in South and Southeast Asia was approximately 3 million ha $\mathrm{yr}^{-1}$, of which 1.2 million ha $\mathrm{yr}^{-1}$ occurred in Indonesia (FAO, 2010). During these 2 decades, the forest loss in the whole of Sumatra was 7.5 million ha, of which 1.1 million ha occurred in Jambi province (Margono et al., 2012). The two most common land uses replacing forests in 
Jambi province are oil palm and rubber plantations. From 2000 to 2010 , the area of rubber plantations in Jambi increased by about $19 \%$, while oil palm plantations increased by $85 \%$ (Luskin et al., 2013). The expansion of rubber and oil palm plantations has increased the income of Jambi, in particular the smallholder farmers (Clough et al., 2016; Rist et al., 2010), which account for $99 \%$ of rubber and $62 \%$ of oil palm land holdings in the Jambi Province. In the whole of Indonesia, $85 \%$ of rubber and $40 \%$ of oil palm plantations are smallholders (DGEC, 2017). However, forest conversion to rubber and oil palm plantations has shown high ecological costs: losses in biodiversity (Clough et al., 2016), decreases in aboveground and belowground organic carbon (C) stocks (Kotowska et al., 2015; van Straaten et al., 2015), reduction in soil nitrogen (N) availability (Allen et al., 2015), decreases in the uptake of methane $\left(\mathrm{CH}_{4}\right)$ from the atmosphere into the soil (Hassler et al., 2015), and increases in soil $\mathrm{N}_{2} \mathrm{O}$ emissions following $\mathrm{N}$ fertilization (Hassler et al., 2017).

Under similar climatic conditions and soil types, the two major factors that influence nutrient leaching losses from forest conversion are soil texture and management practices. Soil texture affects nutrient leaching through its control on soil fertility (e.g., cation exchange capacity, decomposition, and nutrient cycling) and soil water-holding capacity. Finetextured soils have higher cation exchange capacity, decomposition, and soil-N cycling rates, which result in higher soil fertility than coarse-textured soils (Allen et al., 2015; Silver et al., 2000; Sotta et al., 2008). Soil texture also influences water-holding capacity and drainage through its effects on porosity, pore size distribution, and hydraulic conductivity (Hillel, 1982). Clay soils can hold a large amount of water and are dominated by small pores, which have low hydraulic conductivity in high moisture conditions. In contrast, coarse-textured soils have low water-holding capacity and are dominated by large pores, which conduct water rapidly in high moisture conditions and therefore have high potential for leaching of dissolved solutes (Fujii et al., 2009; Lehman and Schroth, 2002). Thus, in heavily weathered soils, such as Acrisols, which dominate the converted lowland landscapes in Jambi, Indonesia (FAO et al., 2012), retention of their inherently low exchangeable base cations in the soil and maintenance of efficient soil-N cycling are largely influenced by soil texture (Allen et al., 2015).

Soil management practices (e.g., fertilizer and lime applications) in converted land uses also play an important role in influencing nutrient leaching, as the magnitude of dissolved nutrients moving downward with water is predominantly driven by the levels of those nutrients in the soil (Dechert et al., 2004, 2005). Without fertilization, nutrient leaching losses in agricultural land usually decrease with years following forest conversion (Dechert et al., 2004). This may be the case for the smallholder rubber plantations in our present study, as these have not been fertilized since conversion from forest (Allen et al., 2015; Hassler et al., 2015, 2017). However, soils in oil palm plantations are very often supplemented with chemical fertilizer and lime applications (Allen et al., 2015; Goh et al., 2003; Hassler et al., 2015, 2017). In cases in which oil palm plantations are regularly fertilized, nutrient leaching losses in older plantations may be higher than in younger ones, as the applied nutrients accumulate in the subsoil over time (Goh et al., 2003; Omoti et al., 1983). Consequently, nutrient leaching in regularly fertilized oil palm plantations will likely be higher than in the original forest. Moreover, in our earlier study conducted in smallholder oil palm plantations, fertilization was shown to decrease microbial $\mathrm{N}$ immobilization due to decreases in microbial biomass (Allen et al., 2015), which could lead to decreases in the retention of $\mathrm{N}$ in the soil.

Despite a growing body of information on the effects of deforestation on soil properties and processes, there is a lack of information on how forest conversion to rubber and oil palm influences nutrient leaching and the efficiency with which nutrients are retained in the soil. This lack is especially notable for nutrients other than $\mathrm{N}$, as previous leaching studies commonly focus on this. Here, we present leaching losses of the full suite of major nutrients using a large-scale replicated design in a region affected by widespread land-use conversion to rubber and oil palm plantations. Our study aimed to assess (1) how soil physical and biochemical characteristics affect nutrient leaching in highly weathered soils and (2) the impact of land-use conversion to smallholder rubber and oil palm plantations on nutrient leaching and on $\mathrm{N}$ and base cation retention efficiency in the soil. We hypothesized that (1) lowland forest and jungle rubber (rubber trees planted in secondary forest), which were the previous land uses before conversion, will have lower leaching losses and higher nutrient retention in clay Acrisol soil than in loam Acrisol soil, and (2) smallholder oil palm plantations with fertilizer and lime applications will have the highest nutrient leaching losses (lowest nutrient retention), whereas smallholder rubber plantations with no fertilizer input will have the lowest nutrient leaching losses.

\section{Materials and methods}

\subsection{Study sites and experimental design}

Our study is part of the ongoing multidisciplinary research project EFForTS (http://www.uni-goettingen.de/en/310995. html, last access: 21 August 2018), investigating the ecological and socioeconomic impact of conversion of lowland forest to rubber and oil palm plantations. The detailed experimental design and locations of the study sites were reported earlier (e.g., Allen et al., 2015; Hassler et al., 2015, 2017). In short, our study region is located in Jambi province, Indonesia $\left(2^{\circ} 0^{\prime} 57^{\prime \prime} \mathrm{S}, 103^{\circ} 15^{\prime} 33^{\prime \prime} \mathrm{E}\right.$; $35-95 \mathrm{~m}$ of elevation). The area has a mean annual air temperature of $26.7 \pm 0.1^{\circ} \mathrm{C}$ and a mean annual precipitation of $2235 \pm 385 \mathrm{~mm}$ (1991-2011; data from a climate station at the Jambi Sultan Thaha air- 
port from the Indonesian Meteorological, Climatological and Geophysical Agency). The dry season $\left(<100 \mathrm{~mm} \mathrm{month}^{-1}\right)$ is from May to September, and the wet season is from October to April. We selected two landscapes within our study region; while both were located on highly weathered Acrisol soils, one has clay-textured soils and the other has loamtextured soils (hereafter we refer to them as clay Acrisol and loam Acrisol soils). Detailed soil characteristics of these classifications are reported by Allen et al. (2016). In summary, the soil textural difference leads to inherent differences in soil fertility (e.g., higher effective cation exchange capacity, base saturation, Bray-extractable $\mathrm{P}$, and lower $\mathrm{Al}$ saturation) in the clay than the loam Acrisols under forest and jungle rubber (Appendix Table A1). Within each soil type, we selected four land uses: lowland forest, jungle rubber, and smallholder plantations of rubber and oil palm (Appendix Table A2). Within each soil type, we had 15 sites (see Allen et al., 2015 for the map of these sites in the study region): 4 forest, 4 jungle rubber, 4 rubber plantations, and 3 oil palm plantations. We started with four oil palm sites within each soil type, but one plantation was sold and the new owner did not continue the collaboration with our research. At another site the instruments for leaching sampling were damaged. In our experimental design, land-use types (including the soil management practices typical for smallholders in the region) were the treatment and the sites were the replications. At each site, we established a plot of $50 \mathrm{~m} \times 50 \mathrm{~m}$. All plots were on the well-drained position of the landscape with slopes ranging from $3 \%-10 \%$ across all plots.

Based on our interviews with the smallholders, their plantations were established after clearing and burning of either forest or jungle rubber and hence these latter land uses served as the reference with which the converted plantations were compared. Additionally, the comparability of the initial soil conditions between the reference and converted land uses was tested using a land-use-independent soil characteristic, i.e., clay content at a depth of 1-2 m (van Straaten et al., 2015); this did not statistically differ among land uses within each soil type (Appendix Table A1; Allen et al., 2015; Hassler et al., 2015). Thus, changes in nutrient leaching can be attributed to land-use conversion with its inherent soil management practices. These first-generation rubber and oil palm plantations were between 7 and 17 years of age. Tree density, height, basal area, and tree species abundance were higher in the reference land uses than the smallholder plantations (Appendix Table A2; Allen et al., 2015; Hassler et al., 2015; Kotowska et al., 2015).

Soil management practices in smallholder oil palm plantations are inherently varied (e.g., fertilization rate), as this depended on the financial resources of the smallholders. Fertilization rates were $48 \mathrm{~kg} \mathrm{~N}, 21 \mathrm{~kg} \mathrm{P}$, and $40 \mathrm{~kg} \mathrm{~K} \mathrm{ha}^{-1} \mathrm{yr}^{-1}$ in the clay Acrisol soil, whereas these were $88 \mathrm{~kg} \mathrm{~N}$, $38 \mathrm{~kg} \mathrm{P}$, and $157 \mathrm{~kg} \mathrm{Kha}^{-1} \mathrm{yr}^{-1}$ (accompanied by $\mathrm{Cl}$ input of $143 \mathrm{~kg} \mathrm{Cl} \mathrm{ha}^{-1} \mathrm{yr}^{-1}$ ) in the loam Acrisol soil. Lime (e.g., $\left.\mathrm{CaMg}\left(\mathrm{CO}_{3}\right)_{2}\right)$, kieserite $\left(\mathrm{MgSO}_{4} \cdot \mathrm{H}_{2} \mathrm{O}\right)$, and borate
$\left(\mathrm{Na}_{2} \mathrm{~B}_{4} \mathrm{O}_{2} \cdot 5 \mathrm{H}_{2} \mathrm{O}\right)$ were also occasionally applied. These fertilization rates are typical of smallholder farms in the region. Soil amendments were applied by hand around each palm tree at $0.8-1.5 \mathrm{~m}$ from the stem base. A combination of manual weeding and herbicides was practiced. Old oil palm fronds were regularly cut and stacked at $4-4.5 \mathrm{~m}$ from the palm rows (row spacing was about $9 \mathrm{~m}$ ). The rubber plantations were not fertilized but were weeded both manually and with herbicides.

\subsection{Lysimeter installation and soil water sampling}

For measuring nutrient leaching, we sampled soil water using lysimeters, which were installed at two randomly chosen locations per replicate plot of the forest, jungle rubber, and rubber plantations. In the oil palm plantations, the lysimeters were deployed according to the spatial structure of the soil management practices: one lysimeter was installed between a distance of $1.3 \mathrm{~m}$ and $1.5 \mathrm{~m}$ from the tree stem where fertilizers were applied, and another lysimeter was installed between a distance of $4 \mathrm{~m}$ and $4.5 \mathrm{~m}$ from the tree stem where the cut fronds were stacked. These suction cup lysimeters (P80 ceramic, maximum pore size $1 \mu \mathrm{m}$; CeramTec AG, Marktredwitz, Germany) were inserted into the soil down to $1.5 \mathrm{~m}$ of depth. This depth was based on our previous work in a lowland forest on highly weathered Ferralsol soil, in which leaching losses were measured at various depth intervals down to $3 \mathrm{~m}$ and from which we found that leaching fluxes did not change below $1 \mathrm{~m}$ (Schwendenmann and Veldkamp, 2005). Moreover, this $1.5 \mathrm{~m}$ depth of the lysimeter installation at our sites was well below the rooting depth, as determined from the fine root biomass distribution with depths (Appendix Fig. B1; Kurniawan, 2016).

Prior to installation, lysimeters, tubes, and collection containers were acid-washed and rinsed with deionized water. Lysimeters were installed in the field 3 months prior to the first sampling. The collection containers (dark glass bottles) were placed in plastic buckets with lids and buried in the ground approximately $2 \mathrm{~m}$ away from the lysimeters. Soil water was sampled biweekly to monthly, depending on the frequency of rainfall, from February to December 2013. Soil water was withdrawn by applying a $40 \mathrm{kPa}$ vacuum on the sampling tube (Dechert et al., 2005; Schwendenmann and Veldkamp, 2005). The collected soil water was then transferred into clean $100 \mathrm{~mL}$ plastic bottles. Upon arrival at the field station, a subsample of $20 \mathrm{~mL}$ was set aside for $\mathrm{pH}$ measurement, while the remaining sample was frozen. All frozen water samples were transported to the University of Göttingen, Germany, and were kept frozen until analysis.

The total dissolved $\mathrm{N}(\mathrm{TDN}), \mathrm{NH}_{4}^{+}, \mathrm{NO}_{3}^{-}$, and $\mathrm{Cl}^{-}$concentrations were measured using continuous-flow injection colorimetry (AA3; SEAL Analytical GmbH, Norderstedt, Germany). TDN was determined by ultraviolet-persulfate digestion followed by hydrazine sulfate reduction (autoanalyzer method G-157-96); $\mathrm{NH}_{4}^{+}$was analyzed by salicylate 
and dichloroisocyanuric acid reaction (autoanalyzer method G-102-93); $\mathrm{NO}_{3}^{-}$by cadmium reduction method with $\mathrm{NH}_{4} \mathrm{Cl}$ buffer (autoanalyzer method G-254-02); and $\mathrm{Cl}^{-}$ was determined with an ion strength adjustor reagent that is pumped through an ion-selective chloride electrode with an integrated reference electrode (autoanalyzer method G-329-05). Dissolved organic N (DON) is the difference between TDN and mineral $\mathrm{N}\left(\mathrm{NH}_{4}^{+}+\mathrm{NO}_{3}^{-}\right)$. Dissolved organic $\mathrm{C}$ (DOC) was determined using a total organic carbon analyzer (TOC-Vwp; Shimadzu Europa GmbH, Duisburg, Germany). DOC was analyzed by pretreating the samples with $\mathrm{H}_{3} \mathrm{PO}_{4}$ solution (to remove inorganic $\mathrm{C}$ ), followed by ultraviolet-persulfate oxidation of organic $\mathrm{C}$ to $\mathrm{CO}_{2}$, which is determined by an infrared detector. Base cations $(\mathrm{Na}, \mathrm{K}$, $\mathrm{Ca}, \mathrm{Mg}$ ), total $\mathrm{Al}$, total $\mathrm{Fe}$, total $\mathrm{Mn}$, total $\mathrm{S}$, total $\mathrm{P}$, and total $\mathrm{Si}$ in soil water were analyzed using an inductively coupled plasma-atomic emission spectrometer (iCAP 6300; Thermo Fischer Scientific GmbH, Dreieich, Germany). Instrument detection limits were $6 \mu \mathrm{g} \mathrm{NH}_{4}^{+}-\mathrm{NL}^{-1}, 5 \mu \mathrm{g} \mathrm{NO}-\mathrm{NL}^{-1}$, $2 \mu \mathrm{TDNL}^{-1}, 4 \mu \mathrm{gOCL}^{-1}, 30 \mu \mathrm{g} \mathrm{Na} \mathrm{L}^{-1}, 50 \mu \mathrm{g} \mathrm{K}^{-1}$, $3 \mu \mathrm{g} \mathrm{Ca} \mathrm{L}{ }^{-1}, \quad 3 \mu \mathrm{gg} \mathrm{L}^{-1}, \quad 2 \mu \mathrm{g} \mathrm{AlL}^{-1}, \quad 3 \mu \mathrm{g} \mathrm{Fe} \mathrm{L}^{-1}$, $2 \mu \mathrm{g} \mathrm{MnL}^{-1}, 10 \mu \mathrm{g} \mathrm{PL}^{-1}, 10 \mu \mathrm{g} \mathrm{SL}^{-1}, 1 \mu \mathrm{g} \mathrm{Si} \mathrm{L}^{-1}$, and $30 \mu \mathrm{g} \mathrm{Cl} \mathrm{L}-1$.

Partial cation-anion charge balance of the major solutes (i.e., those with concentrations $>0.03 \mathrm{mg} \mathrm{L}^{-1}$ ) in soil water was done by expressing solute concentrations in $\mu \operatorname{mol}_{\mathrm{c}} \mathrm{L}^{-1}$ (molar concentration multiplied by the equivalent charge of each solute). Contributions of organic acids $\left(\mathrm{RCOO}^{-}\right)$and bicarbonate $\left(\mathrm{HCO}_{3}^{-}\right)$were calculated, together with $\mathrm{S}$ (having very low concentrations), from the difference between cations and anions. Charge contributions of total $\mathrm{Al}$ were assumed to be $3^{+}$, whereas solutes that had very low concentrations (i.e., total $\mathrm{Fe}, \mathrm{Mn}$, and $\mathrm{P}$ ), and thus had minimal charge contribution, as well as the total dissolved $\mathrm{Si}$ (commonly in a form of monosilicic acid $\left(\mathrm{H}_{4} \mathrm{SiO}_{4}^{0}\right)$ that has no net charge) were excluded (similar to the method used by Hedin et al., 2003).

\subsection{Soil water modeling and calculation of nutrient leaching fluxes}

Drainage water fluxes were estimated using the soil water module of the Expert-N model (Priesack, 2005), which has been used in our earlier work on nutrient leaching losses in Sulawesi, Indonesia (Dechert et al., 2005). The model was parameterized with the characteristics measured at our sites, namely climate data, leaf area index, rooting depth, and soil characteristics. The climate variables included daily air temperature (minimum, maximum, and average), relative humidity, wind speed, solar radiation, and precipitation. For the loam Acrisol soil, the climate data were taken from a climate station at the Harapan Forest Reserve, which was located $10-20 \mathrm{~km}$ from our sites. For the clay Acrisol soil, the climate data were taken from the climate stations at the villages of Lubuk Kepayang and Sarolangun, which were re- spectively $10 \mathrm{~km}$ and $20 \mathrm{~km}$ from our sites. The leaf area indices measured in our forest, jungle rubber, rubber, and oil palm sites in the loam Acrisol soil were 5.8, 4.8, 3.5, and $3.9 \mathrm{~m}^{2} \mathrm{~m}^{-2}$, respectively, and in the clay Acrisol soil were $6.2,4.5,2.8$, and $3.1 \mathrm{~m}^{2} \mathrm{~m}^{-2}$, respectively (Rembold et al., unpublished data). Our measured fine root biomass distribution (Appendix Fig. B1; Kurniawan, 2016) was used to partition root water uptake at various soil depths. Soil characteristics included soil bulk density, texture (Appendix Table A1), and the water retention curve. The latter was determined using the pressure plate method for which intact soil cores $\left(250 \mathrm{~cm}^{3}\right)$ taken at five soil depths $(0.05,0.2,0.4,0.75$, and $1.25 \mathrm{~m}$ ) from each land use within each soil type were measured for water contents at pressure heads of $0,100,330$, and $15000 \mathrm{hPa}$.

Calculation of drainage water fluxes followed the water balance equations:

$\Delta W+D=P-R-\mathrm{ET}$

and

$\mathrm{ET}=I+E+T$,

in which $\Delta W$ is the change in soil water storage, $D$ is drainage water below the rooting zone, $P$ is precipitation, $R$ is runoff, ET is evapotranspiration, $I$ is interception of water by plant foliage, $E$ is evaporation from soil, and $T$ is transpiration by plants. The Expert- $\mathrm{N}$ model calculates actual evapotranspiration using the Penman-Monteith method, runoff based on the site slopes, and vertical water movement using the Richards equation, of which the parameterization of the hydraulic functions were based on our measured soil texture and water retention curve (Mualem, 1976; Van Genuchten, 1980). To validate the output of the water model, we compared the modeled and measured soil matrix potential (Appendix Fig. B2). Soil matrix potential was measured biweekly to monthly from February to December 2013 using tensiometers (P80 ceramic, maximum pore size $1 \mu \mathrm{m}$; CeramTec AG, Marktredwitz, Germany), which were installed at depths of 0.3 and $0.6 \mathrm{~m}$ in two replicate plots per land use within each soil type.

Modeled daily drainage water fluxes at a depth of $1.5 \mathrm{~m}$ were summed to get the biweekly or monthly drainage fluxes. Nutrient leaching fluxes were calculated by multiplying the element concentrations from each of the two lysimeters per replicate plot with the total biweekly or monthly drainage water flux. The annual leaching flux was the sum of biweekly to monthly measured leaching fluxes from February to December 2013, added with the interpolated value for the unmeasured month of January 2013.

\subsection{Nutrient retention efficiency}

To evaluate the efficiency with which nutrients are retained in soil, we calculated the $\mathrm{N}$ and base cation retention efficiency 
Table 1. Simulated water balance during 2013 in different land uses within the loam and clay Acrisol soils in Jambi, Sumatra, Indonesia.

\begin{tabular}{lrrrr}
\hline Water balance components $\left(\mathrm{mm} \mathrm{yr}^{-1}\right)$ & Forest & Jungle rubber & Rubber plantations & Oil palm plantations \\
\hline Loam Acrisol soil (precipitation: $3418 \mathrm{~mm} \mathrm{yr}^{-1}$ ) & & & \\
\hline Evapotranspiration & 1384 & 1224 & 1077 & 1027 \\
Transpiration & 1033 & 815 & 594 & 437 \\
Evaporation & 155 & 213 & 287 & 408 \\
Interception & 196 & 196 & 196 & 182 \\
Water drainage & 1483 & 1487 & 1544 & 1614 \\
Runoff & 545 & 704 & 800 & 761 \\
\hline Clay Acrisol soil (precipitation: $\left.3475 \mathrm{~mm} \mathrm{yr}^{-1}\right)$ & & & 1071 \\
\hline Evapotranspiration & 1622 & 1271 & 1114 & 446 \\
Transpiration & 1284 & 861 & 402 & 459 \\
Evaporation & 157 & 242 & 548 & 166 \\
Interception & 181 & 168 & 164 & 1311 \\
Water drainage & 1117 & 1268 & 1280 & 1087 \\
Runoff & 722 & 932 & 1070 & \\
\hline
\end{tabular}

as follows: 1 minus (nutrient leaching loss / soil-available nutrient) (Hoeft et al., 2014). For the oil palm plantations, we took the average leaching fluxes in the fertilized and frondstacked areas of each plot for calculating the nutrient retention efficiency. This is because these sampling locations may contribute equally in terms of area as both the vertical and lateral flows in the soil profile could influence the sampled drainage water, and thus a wider area may contribute to the sampled drainage water than just the categorized sampling locations. For $\mathrm{N}$ retention efficiency calculation, TDN leaching flux was ratioed to the gross $\mathrm{N}$ mineralization rate as the index of soil-available $\mathrm{N}$, with both terms expressed in $m g \mathrm{~N} \mathrm{~m}^{-2} \mathrm{~d}^{-1}$. For calculation of the base cation retention efficiency, base cation leaching flux was the sum of $\mathrm{K}, \mathrm{Na}$, $\mathrm{Mg}$, and $\mathrm{Ca}$ in units of $\mathrm{mol}_{\text {charge }} \mathrm{m}^{-2} \mathrm{yr}^{-1}$ and soil-available base cations was the sum of these exchangeable cations in units of $\mathrm{mol}_{\text {charge }} \mathrm{m}^{-2}$. We used the measurements of the gross $\mathrm{N}$ mineralization rate in the top $0.05 \mathrm{~m}$ of depth and the stocks of exchangeable bases in the top $0.1 \mathrm{~m}$ of depth (Appendix Table A1; reported by Allen et al., 2015).

\subsection{Supporting parameter: nutrient inputs through bulk precipitation}

In each landscape, we installed two rain samplers in an open area at $1.5 \mathrm{~m}$ above the ground. Rain samplers consisted of $1 \mathrm{~L}$ high-density polyethylene bottles with lids attached to funnels that were covered with a $0.5 \mathrm{~mm}$ sieve and were placed inside polyvinyl chloride tubes (to shield from sunlight and prevent algal growth). Rain samplers were washed with acid and rinsed with deionized water after each collection. Rain was sampled during the same sampling period as the soil water. Each rain sample was filtered through prewashed filter paper ( $4 \mu \mathrm{m}$ pore size) into a $100 \mathrm{~mL}$ plastic bottle and stored frozen for transport to the University of
Göttingen, Germany. The element analyses were the same as those described for soil water. The element concentrations in rainwater were weighted with the rainfall volume during the 2 -week or 1-month collection period to get volume-weighted concentrations. The annual element inputs from bulk precipitation were calculated by multiplying the volume-weighted average element concentrations in a year with the annual rainfall in each landscape.

\subsection{Statistical analysis}

Each replicate plot was represented by the average of two lysimeters, except for the oil palm plantations for which lysimeters in fertilized and frond-stacked areas were analyzed separately. Tests for normality (Shapiro-Wilk test) and homogeneity of variance (Levene's test) were conducted for each variable. Logarithmic or square-root transformation was used for variables that showed non-normal distribution and/or heterogeneous variance. We used linear mixed-effects (LME) models (Crawley, 2009) to (1) assess differences between the two soil types for the reference land uses (to address objective 1) and (2) assess differences among land-use types within each soil type (to address objective 2). The latter was analyzed for each landscape because the fertilization rates applied to the smallholder oil palm plantations inherently differed between the two landscapes. For element concentrations, the LME model had soil type or land use as the fixed effect with spatial replication (plot) and time (biweekly or monthly measurements) as random effects. For the annual leaching fluxes, the LME model had soil type or land use as the fixed effect with spatial replication (plot) as a random effect. If they improved the relative goodness of the model fit (based on the Akaike information criterion), we extended the LME model to include (1) a variance function that allows for different variances of the fixed effect and/or (2) a 
first-order temporal autoregressive process that assumes that correlation between measurement periods decreases with increasing time intervals. Fixed effects were considered significant based on analysis of variance at $P \leq 0.05$, and differences between soil types or land uses were assessed using Fisher's least significant difference test at $P \leq 0.05$. Given the inherent spatial variability in our experimental design, we also considered $P$ values of $>0.05 \leq 0.09$ as marginal significance, mentioned explicitly for some variables. To support the partial charge balance of dissolved cations and anions, we used Pearson correlation analysis to assess the relationships between solute cations and anions using the monthly average $(n=12)$ of the four replicate plots per land use within each soil type. We also used Pearson correlation analysis to test the modeled and measured soil matrix potential using the monthly average $(n=12)$ of the measured two replicate plots per land use within each soil type. To assess how the soil physical and biochemical characteristics (Table A1) influence the annual nutrient leaching fluxes, we conducted a Spearman's rank correlation test for these variables, separately for the reference land uses and the converted land uses across both soil types $(n=16)$. All statistical analyses were conducted using R 3.0.2 (R Development Core Team, 2013).

\section{Results}

\subsection{Water balance and nutrient input from bulk precipitation}

The modeled and measured soil matric potential were highly correlated ( $R=0.79$ to $0.98, n=12, P<0.01$ ) (Appendix Fig. B2). In forest and jungle rubber, modeled annual ET was $36 \%-47 \%$, runoff was $16 \%-27 \%$, and drainage was $32 \%-44 \%$ of annual precipitation. In rubber and oil palm, modeled annual ET was $30 \%-32 \%$, runoff was $22 \%-31 \%$, and drainage was $37 \%-47 \%$ of annual precipitation (Table 1). In both landscapes, annual input from bulk precipitation was dominated by DOC (58\% of total element deposition), followed by $\mathrm{Na}, \mathrm{Cl}, \mathrm{TDN}, \mathrm{Ca}, \mathrm{K}$, and total $\mathrm{S}$ (Table 2). We compared the chlorinity ratios of elements in the bulk precipitation at our sites to those of seawater to infer anthropogenic influence. The average chlorinity ratios from both landscapes were $1.13 \pm 0.05$ for $\mathrm{Na}: \mathrm{Cl}, 0.05 \pm 0.01$ for $\mathrm{Mg}: \mathrm{Cl}, 0.20 \pm 0.02$ for $\mathrm{Ca}: \mathrm{Cl}$, and $0.13 \pm 0.04$ for $\mathrm{K}: \mathrm{Cl}$, which were higher, except for $\mathrm{Mg}: \mathrm{Cl}$, than seawater chlorinity ratios ( 0.56 for $\mathrm{Na}: \mathrm{Cl}, 0.07$ for $\mathrm{Mg}: \mathrm{Cl}, 0.02$ for $\mathrm{Ca}: \mathrm{Cl}$, and 0.02 for $\mathrm{K}: \mathrm{Cl}$; p. 349, Schlesinger and Bernhardt, 2013).

Biogeosciences, 15, 5131-5154, 2018

\subsection{Element concentrations in soil water}

For forest, the loam Acrisol had higher dissolved $\mathrm{Na}, \mathrm{Mg}$, total Al (all $P \leq 0.05), \mathrm{NH}_{4}^{+}-\mathrm{N}, \mathrm{DON}$, total $\mathrm{Fe}$, and $\mathrm{Cl}$ concentrations (all $P \leq 0.09$ ) than the clay Acrisol (Table 3 ). For jungle rubber, the loam Acrisol had higher dissolved $\mathrm{NO}_{3}^{-}-\mathrm{N}(P \leq 0.05)$ and lower total $\mathrm{Si}$ concentrations $(P \leq$ 0.09) than the clay Acrisol (Table 3). The ionic charge concentration of soil solution in the forest sites was higher in the loam $\left(274 \pm 19 \mu \mathrm{mol}_{\text {charge }} \mathrm{L}^{-1}\right)$ than in the clay Acrisols $\left(203 \pm 20 \mu \mathrm{mol}_{\text {charge }} \mathrm{L}^{-1}\right)(P=0.01$; Fig. 1$)$, whereas in the jungle rubber these were comparable (loam Acrisols: $199 \pm$ $31 \mu \mathrm{mol}_{\text {charge }} \mathrm{L}^{-1}$, clay Acrisols: $207 \pm 24 \mu \mathrm{mol}_{\text {charge }} \mathrm{L}^{-1}$; Fig. 1). Correlation analysis of dissolved cations and anions in forest and jungle rubber showed that $\mathrm{NH}_{4}^{+}-\mathrm{N}, \mathrm{Na}, \mathrm{K}, \mathrm{Ca}$, $\mathrm{Mg}$, and total $\mathrm{Al}$ were positively correlated with DON, DOC, $\mathrm{Cl}, \mathrm{NO}_{3}^{-}-\mathrm{N}$, and total S (Appendix Tables A3 and A4).

The rubber plantations in the loam Acrisol had lower $\mathrm{NO}_{3}^{-}-\mathrm{N}, \mathrm{DON}, \mathrm{DOC}, \mathrm{Na}, \mathrm{Ca}, \mathrm{Cl}$ (all $P \leq 0.05$ ), total $\mathrm{P}$, and total $\mathrm{S}$ concentrations (both $P \leq 0.08$ ) than either forest or jungle rubber (Table 3 ). This resulted in a lower ionic charge concentration of soil solution in rubber plantation $\left(200 \pm 21 \mu \mathrm{mol}_{\text {charge }} \mathrm{L}^{-1}\right)$ than in forest $(P<0.01$; Fig. 1$)$. In the clay Acrisol, only dissolved $\mathrm{Na}$ was lower in rubber plantations than in jungle rubber $(P \leq 0.01$; Table 3$)$, and hence the ionic charge concentrations of soil solution in rubber plantation $\left(189 \pm 23 \mu \mathrm{mol}_{\text {charge }} \mathrm{L}^{-1}\right)$ were comparable to those in the reference land uses (Fig. 1). In contrast to the reference land uses, unfertilized rubber plantations showed strong positive correlations of dissolved cations $\left(\mathrm{NH}_{4}^{+}-\mathrm{N}\right.$, $\mathrm{Na}, \mathrm{K}, \mathrm{Ca}, \mathrm{Mg}$, and total $\mathrm{Al}$ ) with $\mathrm{Cl}$ and only weaker positive correlations with DOC or total S (Appendix Tables A3 and A4).

The fertilized areas of oil palm plantations had higher $\mathrm{NO}_{3}^{-}-\mathrm{N}, \mathrm{Na}, \mathrm{Ca}, \mathrm{Mg}$, total $\mathrm{Al}$, and $\mathrm{Cl}$ (all $P \leq 0.05$ ) and lower soil solution $\mathrm{pH}(P=0.07)$ than in the reference land uses within the loam Acrisol soil (Table 3). In the clay Acrisol soil, the fertilized areas of oil palm plantations had higher soil solution $\mathrm{pH}$ and dissolved $\mathrm{Na}$ (both $P \leq 0.05)$, whereas DON was lower $(P=0.08)$ than the reference land uses (Table 3 ). Ionic charge concentrations of soil solutions in the fertilized areas of oil palm plantations $\left(648 \pm 306 \mu \mathrm{mol}_{\text {charge }} \mathrm{L}^{-1}\right.$ for loam Acrisol and $317 \pm$ $83 \mu \mathrm{mol}_{\text {charge }} \mathrm{L}^{-1}$ for clay Acrisol) were higher than in frondstacked areas $\left(190 \pm 23 \mu \mathrm{mol}_{\text {charge }} \mathrm{L}^{-1}\right.$ for loam Acrisol and $173 \pm 37 \mu \mathrm{mol}_{\text {charge }} \mathrm{L}^{-1}$ for clay Acrisol) and in other land uses $(P<0.01$; Fig. 1$)$. In the fertilized areas of the loam Acrisol, dissolved $\mathrm{NO}_{3}^{-}-\mathrm{N}$ was positively correlated with total Al (Table A3) and both were negatively correlated with soil solution $\mathrm{pH}(R=-0.57$ to $-0.76, n=12, P \leq 0.05)$. The fertilized areas showed strong positive correlations of dissolved cations ( $\mathrm{Na}, \mathrm{K}, \mathrm{Ca}, \mathrm{Mg}$, and total $\mathrm{Al}$ ) with total $\mathrm{S}$ or $\mathrm{Cl}$ and only weaker positive correlations with DOC (Appendix Tables A3 and A4). The frond-stacked areas showed 
Table 2. Mean ( \pm SE, $n=2)$ volume-weighted element concentrations and annual inputs in bulk precipitation measured biweekly to monthly from February to December 2013 in the two landscapes with loam and clay Acrisol soils in Jambi, Sumatra, Indonesia.

\begin{tabular}{lrr|rr}
\hline \multirow{2}{*}{ Elements } & \multicolumn{2}{c}{ Volume-weighted concentration $\left(\mathrm{mg} \mathrm{L}^{-1}\right)$} & Annual input $\left(\mathrm{g} \mathrm{m}^{-2} \mathrm{yr}^{-1}\right)$ \\
\cline { 2 - 5 } & Loam Acrisol & Clay Acrisol & Loam Acrisol & Clay Acrisol \\
\hline Ammonium $\left(\mathrm{NH}_{4}^{+}-\mathrm{N}\right)$ & $0.17(0.02)$ & $0.20(0.02)$ & $0.58(0.06)$ & $0.69(0.07)$ \\
Nitrate $\left(\mathrm{NO}_{3}^{-}-\mathrm{N}\right)$ & $0.04(0.02)$ & $0.07(0.01)$ & $0.13(0.06)$ & $0.26(0.04)$ \\
Dissolved organic nitrogen (N) & $0.17(0.01)$ & $0.20(0.04)$ & $0.58(0.02)$ & $0.70(0.14)$ \\
Total dissolved nitrogen (N) & $0.38(0.00)$ & $0.47(0.07)$ & $1.29(0.01)$ & $1.64(0.26)$ \\
Dissolved organic carbon (C) & $8.15(0.19)$ & $7.44(0.07)$ & $27.84(0.66)$ & $25.86(0.25)$ \\
Sodium (Na) & $1.84(0.04)$ & $1.90(0.18)$ & $6.30(0.13)$ & $6.61(0.63)$ \\
Potassium (K) & $0.16(0.04)$ & $0.28(0.14)$ & $0.55(0.15)$ & $0.96(0.49)$ \\
Calcium (Ca) & $0.32(0.02)$ & $0.36(0.07)$ & $1.09(0.08)$ & $1.24(0.24)$ \\
Magnesium (Mg) & $0.07(0.01)$ & $0.09(0.01)$ & $0.24(0.05)$ & $0.30(0.04)$ \\
Total aluminum (Al) & $0.02(0.01)$ & $0.01(0.00)$ & $0.05(0.03)$ & $0.04(0.01)$ \\
Total iron (Fe) & $0.01(0.00)$ & $0.01(0.00)$ & $0.04(0.01)$ & $0.03(0.01)$ \\
Total manganese (Mn) & $0.001(0.00)$ & $0.001(0.00)$ & $0.003(0.00)$ & $0.004(0.00)$ \\
Total phosphorus (P) & $0.01(0.00)$ & $0.02(0.00)$ & $0.04(0.01)$ & $0.08(0.01)$ \\
Total sulfur (S) & $0.26(0.00)$ & $0.30(0.03)$ & $0.90(0.01)$ & $1.04(0.10)$ \\
Total silica (Si) & $0.02(0.01)$ & $0.03(0.01)$ & $0.06(0.02)$ & $0.09(0.03)$ \\
Chloride (Cl) & $1.79(0.25)$ & $1.54(0.30)$ & $6.11(0.84)$ & $5.34(1.06)$ \\
\hline
\end{tabular}

positive correlations of these dissolved cations largely with $\mathrm{Cl}$ (Appendix Tables A3 and A4).

\subsection{Annual leaching flux and nutrient retention efficiency}

For forest, annual leaching fluxes of $\mathrm{Na}, \mathrm{Ca}, \mathrm{Mg}$, total $\mathrm{Al}, \mathrm{Cl}$ (all $P \leq 0.05), \mathrm{NH}_{4}^{+}-\mathrm{N}, \mathrm{DON}$, and total $\mathrm{Si}(P \leq 0.09)$ were larger in the loam than in the clay Acrisols, whereas in jungle rubber only the annual $\mathrm{NO}_{3}^{-}-\mathrm{N}$ leaching flux was larger $(P \leq$ 0.05) (Table 4). Across all forest and jungle rubber sites, annual leaching fluxes of anions (DON and $\mathrm{NO}_{3}^{-}-\mathrm{N}$ ) were negatively correlated with indicators of soil-exchangeable cations (base saturation, effective cation exchange capacity (ECEC), exchangeable Al; Spearman's $\rho=-0.51$ to -0.61 , $n=16, P \leq 0.05$ ), while the annual $\mathrm{NH}_{4}^{+}$-N leaching flux was negatively correlated (Spearman's $\rho=-0.53, n=16$, $P=0.04$ ) with soil organic C (Table A1). For both reference land uses, the higher leaching in loam than in clay Acrisols was mirrored by decreases in $\mathrm{N}$ and base cation retention efficiency in the soil (Table 5). Across all reference sites, $\mathrm{N}$ and base cation retention efficiency in the soil were positively correlated with base saturation, ECEC, and soil organic C (Spearman's $\rho=0.52$ to $0.70, n=16, P \leq 0.04$ ), which in turn were positively correlated with clay content (Spearman's $\rho=0.55$ to $0.59, n=12$ sites analyzed for clay content, $P \leq 0.05$ ).

The rubber plantations had a lower annual $\mathrm{P}$ leaching flux than forests $(P=0.08)$ and a lower annual DOC leaching flux than jungle rubber in the loam Acrisol $(P<0.01)$ (Table 4). $\mathrm{N}$ and base cation retention efficiency in the soil of rubber plantations were comparable with the reference land uses in both soil types (Table 5). In oil palm plantations of the loam Acrisol soil, the fertilized areas had higher annual leaching fluxes of $\mathrm{NO}_{3}^{-}$, TDN, DOC, $\mathrm{Na}, \mathrm{Ca}, \mathrm{Mg}$, total Al, total $\mathrm{S}$, and $\mathrm{Cl}$ (all $P \leq 0.05$ ) than in the unfertilized rubber plantations or the reference land uses, whereas the frond-stacked areas showed comparable leaching fluxes with the other land uses (Table 4). In the loam Acrisol, oil palm plantations had lower $\mathrm{N}$ and base cation retention efficiency in the soil than the other land uses $(P \leq 0.01-0.06$; Table 5). In the clay Acrisol soil, in which leaching fluxes were small (Table 4), there were no differences observed in soil $\mathrm{N}$ and base cation retention efficiency among land uses (Table 5). Across all rubber and oil palm sites, annual $\mathrm{NH}_{4}^{+}$$\mathrm{N}$ and DON leaching fluxes were negatively correlated with ECEC and clay content (Spearman's $\rho=-0.50$ to -0.64 , $n \leq 16, P=0.03-0.07)$. Moreover, base cation retention efficiency in the soil was positively correlated with ECEC, soil organic C, and clay content (Spearman's $\rho=0.68$ to 0.91 , $n \leq 16, P \leq 0.01-0.02$ ), which in turn were correlated with each other (Spearman's $\rho=0.87$ to $0.90, n=12$ sites analyzed for clay content, $P \leq 0.01$ ).

\section{Discussion}

\subsection{Water balance and nutrient input from bulk precipitation}

Our modeled water balance was generally comparable with the estimates from other studies in Indonesia. When compared to a forest at $200-500 \mathrm{~m}$ of elevation on a clay loam soil in Kalimantan (with $28 \%-47 \%$ ET and $40 \%-55 \%$ runoff of 
(a)

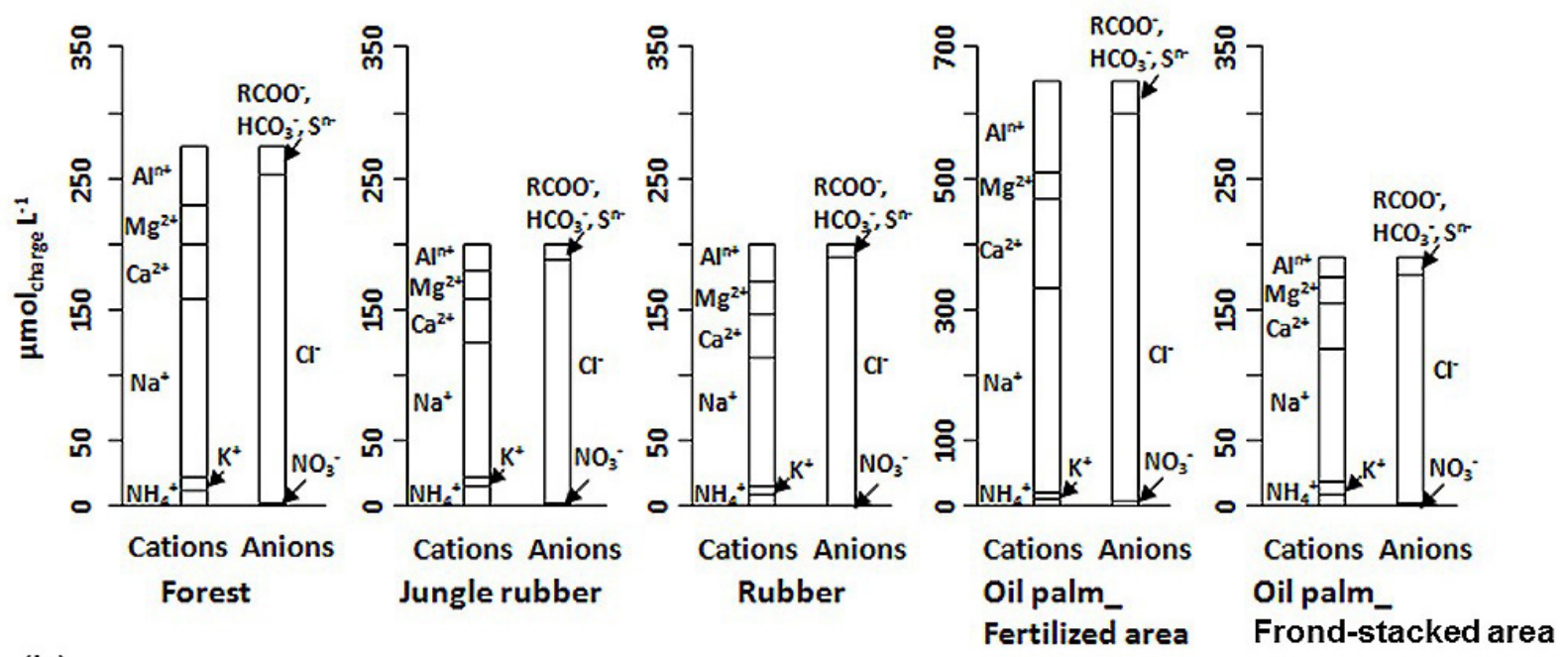

(b)
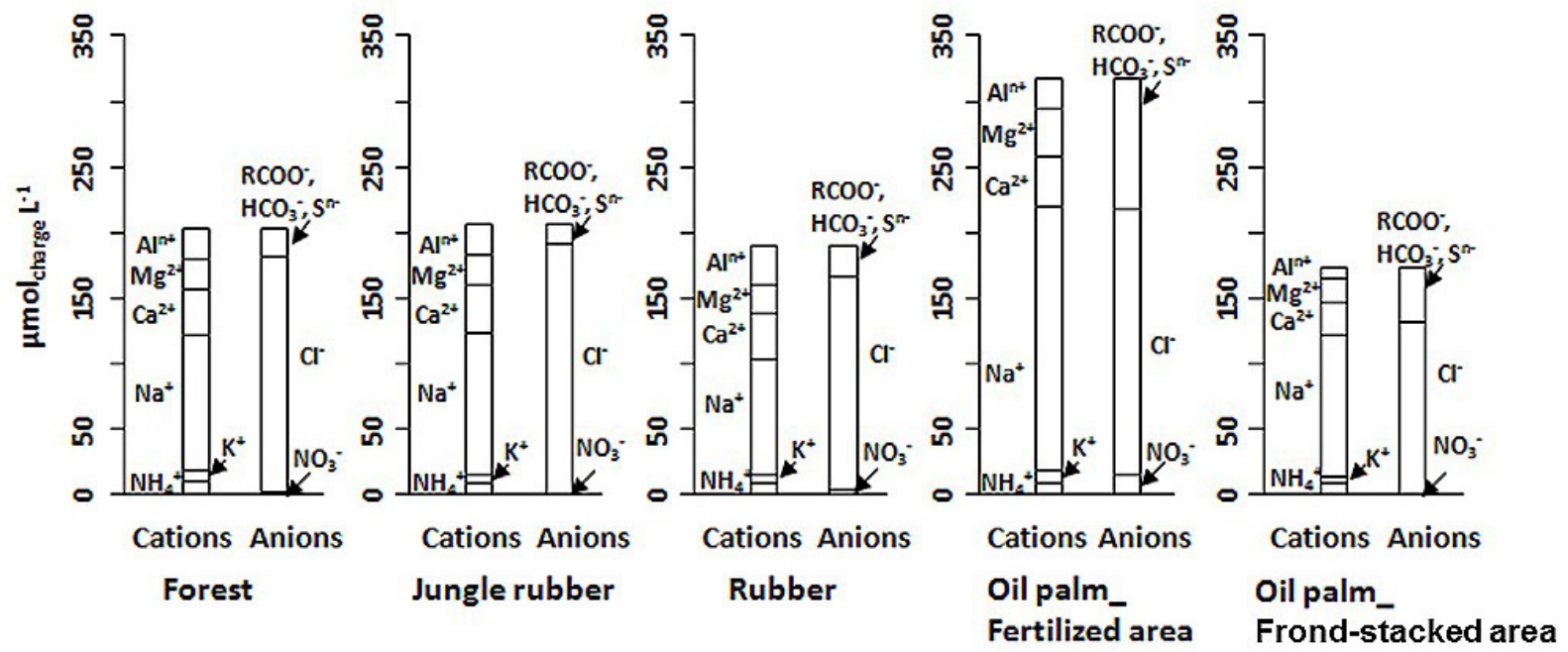

Figure 1. Partial cation-anion charge balance of the major solutes (with concentrations $>0.03 \mathrm{mg} \mathrm{L}^{-1}$ ) in soil water at a depth of $1.5 \mathrm{~m}$ in different land uses within the loam (a) and clay (b) Acrisol soils in Jambi, Sumatra, Indonesia. The $y$ axis scale of the oil palm fertilized area in the loam Acrisol soil is twice that of the other land uses.

$3451 \mathrm{~mm} \mathrm{yr}^{-1}$ precipitation; Suryatmojo et al., 2013), our estimated ET in the forest sites was comparable, although our modeled runoff was lower (Table 1). However, our runoff estimates were similar to the modeled runoff in oil palm and rubber plantations in Jambi province (10\%-20\% of rainfall; Tarigan et al., 2016). Our values for runoff and drainage flux in oil palm plantations (Table 1) were similar to oil palm plantations at $130 \mathrm{~m}$ of elevation on Andisol soils in Papua New Guinea (with $37 \%-57 \%$ ET, $0 \%-44 \%$ runoff, and $38 \%-59 \%$ drainage of $2398-3657 \mathrm{~mm} \mathrm{yr}^{-1}$ precipitation; Banabas et al., 2008). Additionally, our estimated daily ET in oil palm $\left(2.4 \pm 0.1\right.$ and $2.2 \pm 0.1 \mathrm{~mm} \mathrm{~d}^{-1}$ in the loam and clay Acrisols, respectively) was similar to the measurements of Niu et al. (2015) $\left(2.6 \pm 0.7 \mathrm{mmd}^{-1}\right)$ in the same oil palm plantations included in our study. Finally, the high correlations between modeled and measured matric potential ( $0.3 \mathrm{~m}$ of depth; Appendix Fig. B2) suggest that our modeled drainage fluxes closely approximated those in the studied land uses.

The chemical composition of bulk precipitation in our study area was clearly influenced by biomass burning and terrigenous dust from agriculture. This is evident from the high DOC, TDN, $\mathrm{Na}: \mathrm{Cl}, \mathrm{K}: \mathrm{Cl}$, and $\mathrm{Ca}: \mathrm{Cl}$ ratios in bulk precipitation, which were comparable to values of bulk precipitation impacted by such anthropogenic activities in Southeast Asia as well as in Latin America (Balasubramanian et al., 1999; Corre et al., 2010; Eklund et al., 1997). From a peatland in Kalimantan influenced by land-clearing fires, 
Table 3. Mean ( \pm SE, $n=4$, except for oil palm $n=3$ ) nutrient concentrations in soil solutions from a depth of $1.5 \mathrm{~m}$ in different land uses within the loam and clay Acrisol soils in Jambi, Sumatra, Indonesia. Means followed by different lowercase letters indicate significant differences among land uses within each soil type and different uppercase letters indicate significant differences between soil types for each reference land use (linear mixed-effects models with Fisher's LSD test at $P \leq 0.05$ and $\dagger$ at $P \leq 0.09$ for marginal significance).

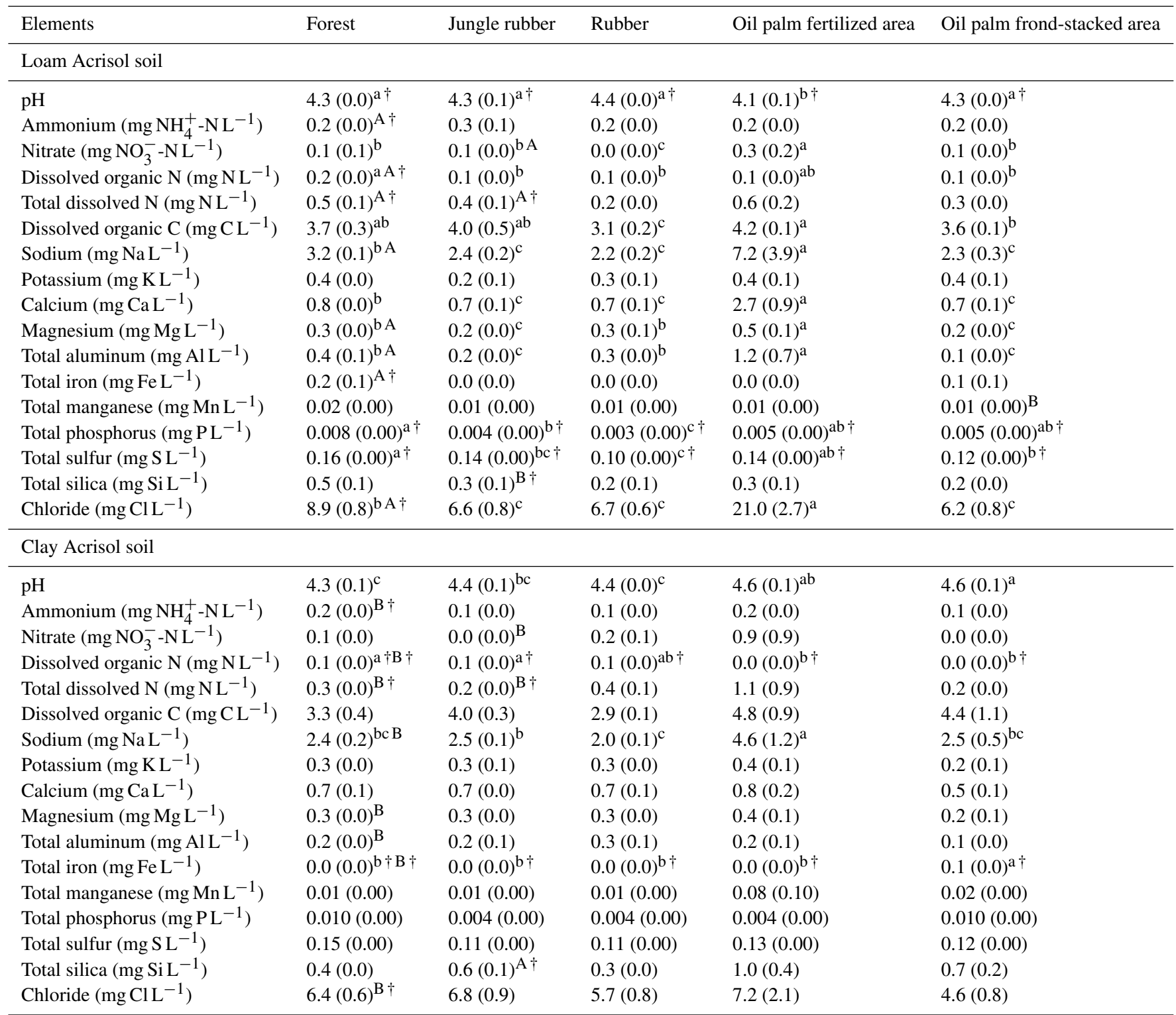

throughfall nutrient depositions (19-22 kg N, 6-11 kg P, 25$44 \mathrm{~kg} \mathrm{Sha}^{-1} \mathrm{yr}^{-1}$ ) are larger than those from bulk precipitation, indicating a large contribution from dry deposition (Ponette-Gonzales et al., 2016). Total (wet + dry) nutrient depositions in our study region could be larger than the values from bulk precipitation. High atmospheric nutrient deposition may have a fertilizing or polluting effect, depending on whether or not the receiving ecosystem is a sink and able to buffer its other cascading effects (e.g., acidification). Additionally, atmospheric redistribution of nutrients in areas with widespread land-use conversion and intensification may have unforeseen effects on downwind and downstream ecosystems (e.g., Bragazza et al., 2006; Sundarambal et al., 2010).

\subsection{Leaching fluxes and nutrient retention efficiency in the reference land uses}

Highly weathered soils (e.g., Acrisols and Ferralsols) are characterized by low solute concentrations in drainage and stream waters due to minimal internal input of rock-derived nutrients via weathering (Hedin et al., 2003; Markewitz et al., 2001). Our reference land uses on Acrisol soils exhib- 
Table 4. Mean ( \pm SE, $n=4$, except for oil palm $n=3$ ) annual (2013) nutrient leaching fluxes measured at a depth of $1.5 \mathrm{~m}$ in different land uses within the loam and clay Acrisol soils in Jambi, Sumatra, Indonesia. Means followed by different lowercase letters indicate significant differences among land uses within each soil type and different uppercase letters indicate significant differences between soil types for each reference land use (linear mixed-effects models with Fisher's LSD test at $P \leq 0.05$ and $\dagger$ at $P \leq 0.09$ for marginal significance).

\begin{tabular}{|c|c|c|c|c|c|}
\hline Elements & Forest & Jungle rubber & Rubber & $\begin{array}{l}\text { Oil palm } \\
\text { fertilized area }\end{array}$ & $\begin{array}{l}\text { Oil palm } \\
\text { frond-stacked area }\end{array}$ \\
\hline \multicolumn{6}{|l|}{ Loam Acrisol soil } \\
\hline Ammonium $\left(\mathrm{g} \mathrm{NH}_{4}^{+}-\mathrm{N} \mathrm{m}^{-2} \mathrm{yr}^{-1}\right)$ & $0.3(0.0)^{\mathrm{ab} \mathrm{A} \dagger}$ & $0.5(0.3)^{\mathrm{a}}$ & $0.2(0.01)^{\mathrm{bc}}$ & $0.3(0.0)^{\mathrm{ab}}$ & $0.2(0.0)^{\mathrm{c}}$ \\
\hline Nitrate $\left(\mathrm{g} \mathrm{NO}_{3}^{-}-\mathrm{N} \mathrm{m}^{-2} \mathrm{yr}^{-1}\right)$ & $0.1(0.1)^{\mathrm{ab}}$ & $0.1(0.1)^{\mathrm{ab} \mathrm{A}}$ & $0.0(0.0)^{\mathrm{b}}$ & $0.6(0.3)^{\mathrm{a}}$ & $0.1(0.0)^{\mathrm{ab}}$ \\
\hline Dissolved organic $\mathrm{N}\left(\mathrm{g} \mathrm{N} \mathrm{m}^{-2} \mathrm{yr}^{-1}\right)$ & $0.2(0.0)^{\mathrm{A} \dagger}$ & $0.1(0.0)$ & $0.1(0.0)$ & $0.2(0.1)$ & $0.1(0.0)$ \\
\hline Total dissolved $\mathrm{N}\left(\mathrm{g} \mathrm{N} \mathrm{m}^{-2} \mathrm{yr}^{-1}\right)$ & $0.6(0.1)^{\mathrm{ab} \dagger \mathrm{A} \dagger}$ & $0.8(0.3)^{\mathrm{ab} \dagger}$ & $0.4(0.0)^{\mathrm{b} \dagger}$ & $1.1(0.3)^{\mathrm{a} \dagger}$ & $0.4(0.1)^{\mathrm{b} \dagger}$ \\
\hline Dissolved organic $\mathrm{C}\left(\mathrm{g} \mathrm{C} \mathrm{m}^{-2} \mathrm{yr}^{-1}\right)$ & $4.2(0.5)^{\mathrm{bc}}$ & $6.2(1.5)^{\mathrm{ab}}$ & $3.9(0.2)^{\mathrm{c}}$ & $7.3(0.2)^{\mathrm{a}}$ & $4.2(0.4)^{\mathrm{bc}}$ \\
\hline Sodium $\left(\mathrm{g} \mathrm{Na} \mathrm{m}^{-2} \mathrm{yr}^{-1}\right)$ & $3.8(0.4)^{\mathrm{b} \mathrm{A}}$ & $3.7(0.8)^{\mathrm{b}}$ & $3.1(0.3)^{b}$ & $13.1(7.6)^{\mathrm{a}}$ & $3.1(0.5)^{\mathrm{b}}$ \\
\hline Potassium $\left(\mathrm{g} \mathrm{K} \mathrm{m}^{-2} \mathrm{yr}^{-1}\right)$ & $0.4(0.1)$ & $0.4(0.2)$ & $0.4(0.1)$ & $0.7(0.2)$ & $0.4(0.1)$ \\
\hline Calcium $\left(\mathrm{g} \mathrm{Ca} \mathrm{m}^{-2} \mathrm{yr}^{-1}\right)$ & $1.0(0.1)^{\mathrm{b} \mathrm{A}}$ & $1.2(0.3)^{\mathrm{b}}$ & $0.9(0.1)^{\mathrm{b}}$ & $4.6(1.3)^{\mathrm{a}}$ & $1.0(0.2)^{\mathrm{b}}$ \\
\hline Magnesium ( $\left.\mathrm{g} \mathrm{Mg} \mathrm{m}^{-2} \mathrm{yr}^{-1}\right)$ & $0.4(0.0)^{\mathrm{b} \mathrm{A}}$ & $0.4(0.1)^{b}$ & $0.4(0.1)^{b}$ & $0.9(0.2)^{\mathrm{a}}$ & $0.3(0.1)^{\mathrm{b}}$ \\
\hline Total aluminum $\left(\mathrm{g} \mathrm{Al} \mathrm{m}^{-2} \mathrm{yr}^{-1}\right)$ & $0.4(0.1)^{\mathrm{b} \mathrm{A}}$ & $0.3(0.1)^{b}$ & $0.4(0.0)^{b}$ & $2.3(1.3)^{\mathrm{a}}$ & $0.2(0.0)^{\mathrm{b}}$ \\
\hline Total iron $\left(\mathrm{g} \mathrm{Fe} \mathrm{m}^{-2} \mathrm{yr}^{-1}\right)$ & $0.20(0.10)$ & $0.02(0.01)$ & $0.03(0.01)$ & $0.04(0.00)$ & $0.10(0.10)$ \\
\hline Total manganese $\left(\mathrm{g} \mathrm{Mn} \mathrm{m}^{-2} \mathrm{yr}^{-1}\right)$ & $0.02(0.01)$ & $0.03(0.02)$ & $0.01(0.01)$ & $0.03(0.00)$ & $0.01(0.00)$ \\
\hline Total phosphorus $\left(\mathrm{g} \mathrm{P} \mathrm{m}^{-2} \mathrm{yr}^{-1}\right)$ & $0.01(0.00)^{\mathrm{a} \dagger}$ & $0.01(0.00)^{\mathrm{abc} \dagger}$ & $0.00(0.00)^{\mathrm{c} \dagger}$ & $0.01(0.00)^{\mathrm{ab} \dagger}$ & $0.01(0.00)^{\mathrm{bc} \dagger}$ \\
\hline Total sulfur $\left(\mathrm{g} \mathrm{S} \mathrm{m}^{-2} \mathrm{yr}^{-1}\right)$ & $0.20(0.00)^{\mathrm{ab}}$ & $0.20(0.10)^{\mathrm{ab}}$ & $0.13(0.01)^{\mathrm{b}}$ & $0.24(0.0)^{\mathrm{a}}$ & $0.15(0.0)^{\mathrm{ab}}$ \\
\hline Total silica $\left(\mathrm{g} \mathrm{Si} \mathrm{m}^{-2} \mathrm{yr}^{-1}\right)$ & $0.7(0.2)^{\mathrm{A} \dagger}$ & $0.6(0.3)$ & $0.4(0.1)$ & $0.4(0.1)$ & $0.3(0.1)$ \\
\hline Chloride $\left(\mathrm{g} \mathrm{Cl} \mathrm{m}^{-2} \mathrm{yr}^{-1}\right)$ & $10.5(0.9)^{\mathrm{b} \mathrm{A}}$ & $11.5(2.4)^{b}$ & $9.1(0.6)^{b}$ & $38.0(6.7)^{\mathrm{a}}$ & $7.8(1.2)^{b}$ \\
\hline \multicolumn{6}{|l|}{ Clay Acrisol soil } \\
\hline Ammonium $\left(\mathrm{g} \mathrm{NH}_{4}^{+}-\mathrm{N} \mathrm{m}^{-2} \mathrm{yr}^{-1}\right)$ & $0.2(0.0)^{\mathrm{B} \dagger}$ & $0.2(0.0)$ & $0.2(0.0)$ & $0.2(0.0)$ & $0.2(0.0)$ \\
\hline Nitrate $\left(\mathrm{g} \mathrm{NO}_{3}^{-}-\mathrm{N} \mathrm{m}^{-2} \mathrm{yr}^{-1}\right)$ & $0.1(0.1)$ & $0.0(0.0)^{\mathrm{B}}$ & $0.3(0.2)$ & $1.1(1.1)$ & $0.0(0.0)$ \\
\hline Dissolved organic $\mathrm{N}\left(\mathrm{g} \mathrm{N} \mathrm{m}^{-2} \mathrm{yr}^{-1}\right)$ & $0.1(0.0)^{\mathrm{B} \dagger}$ & $0.1(0.0)$ & $0.1(0.0)$ & $0.1(0.0)$ & $0.1(0.0)$ \\
\hline Total dissolved $\mathrm{N}\left(\mathrm{g} \mathrm{N} \mathrm{m}^{-2} \mathrm{yr}^{-1}\right)$ & $0.3(0.1)^{\mathrm{B} \dagger}$ & $0.3(0.0)$ & $0.6(0.2)$ & $1.4(1.1)$ & $0.3(0.0)$ \\
\hline Dissolved organic $\mathrm{C}\left(\mathrm{g} \mathrm{C} \mathrm{m}^{-2} \mathrm{yr}^{-1}\right)$ & $3.4(0.4)^{\mathrm{c}}$ & $5.4(0.7)^{\mathrm{ab}}$ & $3.6(0.2)^{\mathrm{bc}}$ & $6.2(1.4)^{\mathrm{a}}$ & $5.6(1.0)^{\mathrm{ab}}$ \\
\hline Sodium $\left(\mathrm{g} \mathrm{Na} \mathrm{m}^{-2} \mathrm{yr}^{-1}\right)$ & $2.5(0.4)^{\mathrm{bB}}$ & $3.2(0.3)^{b}$ & $2.5(0.1)^{b}$ & $6.3(1.8)^{\mathrm{a}}$ & $3.3(0.6)^{b}$ \\
\hline Potassium $\left(\mathrm{g} \mathrm{K} \mathrm{m}^{-2} \mathrm{yr}^{-1}\right)$ & $0.3(0.0)$ & $0.3(0.1)$ & $0.3(0.1)$ & $0.5(0.1)$ & $0.2(0.1)$ \\
\hline Calcium $\left(\mathrm{g} \mathrm{Ca} \mathrm{m}^{-2} \mathrm{yr}^{-1}\right)$ & $0.7(0.1)^{\mathrm{B}}$ & $0.9(0.0)$ & $0.8(0.1)$ & $1.0(0.2)$ & $0.7(0.1)$ \\
\hline Magnesium $\left(\mathrm{g} \mathrm{Mg} \mathrm{m}^{-2} \mathrm{yr}^{-1}\right)$ & $0.2(0.0)^{\mathrm{bB}}$ & $0.3(0.0)^{\mathrm{b}}$ & $0.3(0.0)^{\mathrm{b}}$ & $0.6(0.1)^{\mathrm{a}}$ & $0.2(0.1)^{\mathrm{b}}$ \\
\hline Total aluminum $\left(\mathrm{g} \mathrm{Al} \mathrm{m}^{-2} \mathrm{yr}^{-1}\right)$ & $0.2(0.0)^{\mathrm{B}}$ & $0.2(0.1)$ & $0.3(0.1)$ & $0.3(0.1)$ & $0.1(0.0)$ \\
\hline Total iron $\left(\mathrm{g} \mathrm{Fe} \mathrm{m}^{-2} \mathrm{yr}^{-1}\right)$ & $0.02(0.00)$ & $0.03(0.00)$ & $0.02(0.00)$ & $0.01(0.0)$ & $0.06(0.05)$ \\
\hline Total manganese $\left(\mathrm{g} \mathrm{Mn} \mathrm{m}^{-2} \mathrm{yr}^{-1}\right)$ & $0.01(0.00)$ & $0.01(0.00)$ & $0.01(0.00)$ & $0.09(0.07)$ & $0.02(0.00)$ \\
\hline Total phosphorus $\left(\mathrm{g} \mathrm{P} \mathrm{m}^{-2} \mathrm{yr}^{-1}\right)$ & $0.01(0.00)$ & $0.01(0.00)$ & $0.01(0.00)$ & $0.01(0.00)$ & $0.02(0.01)$ \\
\hline Total sulfur $\left(\mathrm{g} \mathrm{S} \mathrm{m}^{-2} \mathrm{yr}^{-1}\right)$ & $0.16(0.0)^{\mathrm{ab}}$ & $0.15(0.0)^{\mathrm{ab}}$ & $0.14(0.0)^{b}$ & $0.17(0.0)^{\mathrm{a}}$ & $0.17(0.0)^{\mathrm{ab}}$ \\
\hline Total silica $\left(\mathrm{g} \mathrm{Si} \mathrm{m}^{-2} \mathrm{yr}^{-1}\right)$ & $0.3(0.1)^{\mathrm{bB} \dagger}$ & $0.7(0.1)^{\mathrm{ab}}$ & $0.3(0.0)^{b}$ & $1.3(0.6)^{\mathrm{a}}$ & $0.8(0.3)^{\mathrm{ab}}$ \\
\hline Chloride $\left(\mathrm{g} \mathrm{Cl} \mathrm{m}^{-2} \mathrm{yr}^{-1}\right)$ & $6.0(0.3)^{\mathrm{B}}$ & $8.2(1.3)$ & $6.9(1.0)$ & $9.8(3.0)$ & $5.6(0.6)$ \\
\hline
\end{tabular}

ited comparably low ionic charge concentrations with high dissolved Al (Fig. 1), as reported by Hedin et al. (2003) and Markewitz et al. (2001). Soil nutrients in such highly weathered soils are conserved through efficient cycling between the soil and vegetation, for which soil texture is one important controlling factor. For example, fine-textured Acrisol and Ferralsol soils show higher nutrient- and water-holding capacity, higher soil $\mathrm{N}$ availability, decomposition rate, and plant productivity than the coarse-textured soils of the same groups (e.g., Ohta et al., 1993; Silver et al., 2000; Sotta et al., 2008). Our measured nutrient leaching losses concurred with these findings. The lower annual nutrient leaching fluxes in clay as compared to loam Acrisols (i.e., TDN, $\mathrm{Na}, \mathrm{Ca}, \mathrm{Mg}$; Table 4) were paralleled by higher gross rates of $\mathrm{NH}_{4}^{+}$production and immobilization (Allen et al., 2015), soil N stocks, ECEC, base saturation (Appendix Table A1), and water-holding capacity (Hassler et al., 2015). Nutrient demand of vegetation may not be the dominant control on leaching fluxes, as the vegetation structure of the reference land uses (tree density, basal area, root biomass; Appendix 
Table 5. Mean ( \pm SE, $n=4$, except for oil palm $n=3$ ) nitrogen and base cation retention efficiency in soils under different land uses within the loam and clay Acrisol soils in Jambi, Sumatra, Indonesia. Means followed by different lowercase letters indicate significant differences among land uses within each soil type and different uppercase letters indicate significant differences between soil types for each reference land use (linear mixed-effects models with Fisher's LSD test at $P \leq 0.05$ and $\dagger$ at $P=0.07$ for marginal significance).

\begin{tabular}{|c|c|c|c|c|}
\hline Characteristic & Forest & Jungle rubber & Rubber & Oil palm \\
\hline \multicolumn{5}{|l|}{ Loam Acrisol soil } \\
\hline $\begin{array}{l}\mathrm{N} \text { retention efficiency } \\
\left(\mathrm{mg} \mathrm{N} \mathrm{m}^{-2} \mathrm{~d}^{-1} / \mathrm{mg} \mathrm{N} \mathrm{m}^{-2} \mathrm{~d}^{-1}\right)\end{array}$ & $0.997(0.000)^{\mathrm{a} B}$ & $0.996(0.001)^{\mathrm{a} B \dagger}$ & $0.998(0.000)^{\mathrm{a}}$ & $0.995(0.001)^{b}$ \\
\hline $\begin{array}{l}\text { Base cation retention efficiency } \\
\left(\mathrm{mol}_{\text {charge }} \mathrm{m}^{-2} \mathrm{yr}^{-1} / \mathrm{mol}_{\text {charge }} \mathrm{m}^{-2}\right)\end{array}$ & $0.455(0.094)^{\mathrm{a} \dagger \mathrm{B}}$ & $0.591(0.088)^{\mathrm{a} \dagger \mathrm{B} \dagger}$ & $0.699(0.083)^{\mathrm{a} \dagger}$ & $0.280(0.128)^{b \dagger}$ \\
\hline \multicolumn{5}{|l|}{ Clay Acrisol soil } \\
\hline $\begin{array}{l}\mathrm{N} \text { retention efficiency } \\
\left(\mathrm{mg} \mathrm{N} \mathrm{m}^{-2} \mathrm{~d}^{-1} / \mathrm{mg} \mathrm{N} \mathrm{m}^{-2} \mathrm{~d}^{-1}\right)\end{array}$ & $0.999(0.000)^{\mathrm{A}}$ & $0.999(0.000)^{\mathrm{A} \dagger}$ & $0.997(0.001)$ & $0.998(0.001)$ \\
\hline $\begin{array}{l}\text { Base cation retention efficiency } \\
\left(\mathrm{mol}_{\text {charge }} \mathrm{m}^{-2} \mathrm{yr}^{-1} / \mathrm{mol}_{\text {charge }} \mathrm{m}^{-2}\right)\end{array}$ & $0.812(0.084)^{\mathrm{A}}$ & $0.852(0.083)^{\mathrm{A} \dagger}$ & $0.841(0.025)$ & $0.894(0.028)$ \\
\hline
\end{tabular}

Table A2) even seemed larger in the loam than the clay Acrisols. Similarly, the differences in tree species compositions between the loam and clay Acrisol soils (Appendix Table A2) may not have dominantly influenced the nutrient leaching fluxes, as supported by the comparable net primary production of the reference land uses between soil types (Kotowska et al., 2015). Our findings showed that soil texture was the main factor regulating nutrient leaching losses and soil fertility (e.g., nutrient stocks and $\mathrm{N}$ cycling rates) in these highly weathered Acrisol soils.

The influence of soil texture on soil biochemical characteristics is also linked to the leaching losses or, conversely, nutrient retention efficiency. This was shown by the negative correlations of annual DON and $\mathrm{NO}_{3}^{-}-\mathrm{N}$ leaching losses with soil base saturation, ECEC, and exchangeable $\mathrm{Al}$ across all the reference sites. The higher the $\mathrm{N}$ and cation leaching (as in the loam Acrisol), the lower the cation stocks and ECEC in the soil (Appendix Table A1). Similarly, the negative correlation of annual $\mathrm{NH}_{4}^{+}-\mathrm{N}$ leaching losses with soil organic $\mathrm{C}$ suggests high retention of $\mathrm{NH}_{4}^{+}$in the clay Acrisol that has higher soil organic $\mathrm{C}$ (Appendix Table A1), higher soil microbial biomass, and higher gross rates of $\mathrm{NH}_{4}^{+}$cycling than in the loam Acrisol (Allen et al., 2015). These all led to the higher $\mathrm{N}$ and base cation retention efficiency in clay than in loam Acrisols (Table 5). The positive correlations of $\mathrm{N}$ and base cation retention efficiency with soil base saturation, ECEC, organic $\mathrm{C}$, and clay content across all the reference sites suggest efficient cycling of nutrients between the soil and vegetation in the clay Acrisol.

\subsection{Land-use change effects on leaching fluxes and nutrient retention efficiency}

Land-use conversion (i.e., slashing and burning of the previous vegetation) causes a large portion of nutrients in biomass to be lost during burning (Kaufmann et al., 1995; Mackensen et al., 1996) and, after the initial pulse of nutrient release from ashes and decomposition, nutrient leaching continuously decreases with time (Klinge et al., 2004). Our smallholder rubber plantations were not fertilized during our study years, in part because the price of rubber was low during those years (Clough et al., 2015). Without soil amendments, soil nutrient levels can decrease significantly years after land-use conversion (e.g., decreases in exchangeable bases, Dechert et al., 2004; P availability, Ngoze et al., 2008; soil-N cycling rate and microbial N, Allen et al., 2015; Corre et al., 2006; Davidson et al., 2007). This was evident in our unfertilized rubber plantations with low ionic charge concentrations of soil solutions in the loam Acrisol soil (Fig. 1; Table 3). The annual $\mathrm{P}$ leaching flux in rubber decreased (Table 4) and was reflected by a decrease in Bray-extractable $\mathrm{P}$ compared to forest (Allen et al., 2016). Compared to forest, the decrease in annual DOC leaching flux in rubber (Table 4) was mirrored by decreases in microbial C (Allen et al., 2015), litterfall, and root production (Kotowska et al., 2015) in the same rubber plantations and the overall decrease in soil organic C stocks in smallholder rubber plantations in the same study region (van Straaten et al., 2015). Decreases in DOC concentrations of soil solutions were possibly the reason why cations in the soil solutions of the rubber plantations were strongly correlated with $\mathrm{Cl}$ and only weakly correlated with organic-associated anions (DOC or total S; Appendix Tables A3 and A4). Our results showed that disruption of nutrient cycling between the soil and vegetation brought about by 
land-use conversion to rubber plantations, combined with the absence of soil amendments, had decreased nutrient leaching (Tables 3 and 4) as well as soil nutrient availability (i.e., $\mathrm{P}$ stocks, microbial $\mathrm{N}$, gross $\mathrm{N}$ mineralization rates; Allen et al., 2015, 2016).

The most important factor influencing nutrient leaching in the smallholder oil palm plantations was fertilizer application. This was evident by the higher solute concentrations of the fertilized area compared to the frond-stacked area and to the other land uses (Fig. 1; Table 3). In the fertilized area, the stronger correlations of dissolved cations with total $\mathrm{S}$ and $\mathrm{Cl}$, rather than with DOC, were because $\mathrm{S}$ and $\mathrm{Cl}$ are components of the applied fertilizers (see Sect. 2.1). The larger increases in solute concentrations of the fertilized areas in the loam Acrisol than the clay Acrisol soils were attributed to the following: (1) higher fertilization rates of oil palm plantations in the loam Acrisol (see Sect. 2.1) and (2) its lower clay contents that contributed to its lower water-holding capacity and nutrient retention (Tables 1 and 5). In fertilized areas of the loam Acrisol, the correlations among dissolved $\mathrm{NO}_{3}^{-}$, total $\mathrm{Al}$, and acidity were likely due to nitrification of added $\mathrm{N}$ fertilizer and the low acid-buffering capacity of this loam Acrisol soil (i.e., low base saturation; Appendix Table A1; Allen et al., 2016). Soil-extractable $\mathrm{NO}_{3}^{-}$and $\mathrm{NH}_{4}^{+}$in these smallholder plantations are elevated up to 6 weeks following fertilization (Hassler et al., 2017), during which time $\mathrm{NO}_{3}^{-}$is susceptible to leaching. Nitrification-induced acidity may have enhanced the $\mathrm{Al}$ acid-buffering reaction and led to the increases in dissolved $\mathrm{Al}$ and acidity of soil solution (Table 3). Other studies in Indonesia and Malaysia have also reported increases in soil acidity due to $\mathrm{N}$ fertilization in oil palm plantations (Anuar et al., 2008; Comte et al., 2013). Even though occasional liming is practiced by smallholders in these oil palm plantations, soil $\mathrm{pH}$ (Appendix Table A1) was still within the $\mathrm{Al}$ acid-buffering range ( $\mathrm{pH} 3-5$; Van Breemen et al., 1983). The acidic soil water and elevated dissolved $\mathrm{Al}$ concentration resulting from $\mathrm{N}$ fertilization in these oil palm plantations may have also triggered the decrease in mycorrhizal colonization of fine roots and the increase in distorted root tips found at the same sites (Sahner et al., 2015).

In the fertilized areas of oil palm plantations in the loam Acrisol, increased annual leaching fluxes of $\mathrm{Na}$, total $\mathrm{S}, \mathrm{Cl}$, $\mathrm{NO}_{3}^{-}$, TDN, $\mathrm{Ca}$, and $\mathrm{Mg}$ (Table 4) were due to applications of Na-, S-, and N-containing fertilizers and lime (see Sect. 2.1). The leaching losses in our oil palm plantations were lower than those reported for oil palm plantations on Acrisol soils in Nigeria (2.6 $\mathrm{g} \mathrm{Ca} \mathrm{m}^{-2}$ and $0.6 \mathrm{~g} \mathrm{Mg} \mathrm{m}^{-2}$ during a 6-month period; Omoti et al., 1983) and Malaysia $\left(0.3-0.6 \mathrm{~g} \mathrm{~N} \mathrm{~m}^{-2}\right.$ during a 5-month period; Tung et al., 2009) and on Andisol soils in Papua New Guinea (3.7-10.3 $\mathrm{g} \mathrm{N} \mathrm{m}^{-2} \mathrm{yr}^{-1}$ during a 14-month period; Banabas et al., 2008), all of which had larger fertilization rates than our smallholders. Moreover, the increased annual DOC fluxes in fertilized areas of oil palm plantations (Table 4) suggest a reduction in the retention of
DOC in the soil. This, combined with the decreases in litterfall and root production, harvest export (Kotowska et al., 2015), and decreases in soil $\mathrm{CO}_{2}$ emissions (Hassler et al., 2015) from the same oil palm plantations, provided additional support for the decreases in soil organic $\mathrm{C}$ stocks in smallholder oil palm plantations in the same study region (van Straaten et al., 2015). Altogether, our results showed the overarching influence of soil texture on nutrient retention or leaching in these converted land uses. This was shown by the positive correlations of annual $\mathrm{NH}_{4}^{+}-\mathrm{N}$ leaching, annual DON leaching, and base cation retention efficiency with ECEC, soil organic $\mathrm{C}$, and clay content across all sites of the converted land uses.

The fertilization rates in our studied smallholder oil palm plantations were only 2-5 times lower than the nearby large-scale plantations, which were typically 230 $260 \mathrm{~kg} \mathrm{~N} \mathrm{ha}^{-1} \mathrm{yr}^{-1}$. Our findings of increased TDN and base cation leaching or decreased retention efficiency, particularly in the loam Acrisol, despite the low fertilization rates (Tables 4 and 5), imply a need to optimize the fertilization rates in large-scale plantations, especially on coarse-textured soils that have low inherent nutrient retention, in order to minimize the environmental effect while maintaining production.

\section{Conclusions}

The low solute concentrations in drainage water of the reference land uses signified low internal inputs of rock-derived nutrients in these highly weathered soils and suggest efficient internal cycling of nutrients. Our findings of lower nutrient leaching losses and higher nutrient retention efficiency in the reference land uses on the clay as compared to the loam Acrisol soils supported our first hypothesis and reflected the influence of soil texture on nutrient retention and water-holding capacity. The low nutrient leaching losses in the unfertilized rubber plantations and the high leaching in the fertilized oil palm plantations supported our second hypothesis. Reduced $\mathrm{P}$ and DOC leaching in rubber plantations signaled a reduction in nutrient levels, which may influence how long these rubber plantations can remain before conversion to another land use. The sustainability of oil palm plantations must take into account the long-term effect of chronic $\mathrm{N}$ fertilization on soil water acidity and $\mathrm{Al}$ solubility; the inherently low acid-buffering capacity of Acrisol soils implies that the smallholders will be increasingly dependent on lime application, which entails additional capital input. Our results highlight the need to develop soil management practices that conserve soil nutrients in unfertilized rubber plantations and increase nutrient retention efficiency in fertilized oil palm plantations. Management practices to regulate leaching losses are possibly more pressing for large-scale oil palm plantations, which have 2-5 times higher fertilization rates and may have a larger impact on groundwater quality than the smallholders. Process-based models, used to predict 
yield and the associated environmental footprint of these tree cash-crop plantations, should reflect the differences in soil management (e.g., absence or low vs. high fertilization rates, weed control) between smallholder and large-scale plantations. For valid large-scale extrapolation, quantification of leaching losses in oil palm plantations should not only represent the spatial structure of management practices but also surface landforms, which influence water redistribution (e.g., inclusion of riparian areas), and an improved water budget (e.g., estimates of evapotranspiration from inter-rows).

Data availability. Our data are deposited in the EFForTS-IS data repository (https://efforts-is.uni-goettingen.de, last access: 15 September 2015), an internal data-exchange platform, which is accessible to EFForTS members only. Based on a data sharing agreement within EFForTS, these data are currently not publicly accessible but will be made available through a written request to the corresponding and senior authors. 
Appendix A: Soil and vegetation characteristics and Pearson correlations among solute concentrations in each land use within each soil type

Table A1. Soil characteristics in the top $0.1 \mathrm{~m}$ of soil (except for clay content, which is for $1-2 \mathrm{~m}$ ) in different land uses within the loam and clay Acrisol soils in Jambi, Sumatra, Indonesia. Means ( \pm SE, $n=4$, except for clay content $n=3$ ) followed by different lowercase letters indicate significant differences among land uses within each soil type and different uppercase letters indicate significant differences between soil types for each reference land use (linear mixed-effects models with Fisher's LSD test at $P \leq 0.05$ and $\dagger$ at $P \leq 0.09$ for marginal significance). These soil characteristics were reported by Allen et al. (2015).

\begin{tabular}{|c|c|c|c|c|}
\hline Characteristic-land use & Forest & Jungle rubber & Rubber plantation & Oil palm plantation \\
\hline \multicolumn{5}{|l|}{ Loam Acrisol soil } \\
\hline Bulk density $\left(\mathrm{g} \mathrm{cm}^{-3}\right)$ & $1.0(0.04)^{\mathrm{ab}}$ & $0.9(0.03)^{\mathrm{b} \mathrm{A}}$ & $1.1(0.1)^{\mathrm{a}}$ & $1.1(0.1)^{\mathrm{a}}$ \\
\hline $\mathrm{pH}\left(1: 4 \mathrm{H}^{2} \mathrm{O}\right)$ & $4.3(0.04)^{\mathrm{b} \dagger}$ & $4.3(0.03)^{\mathrm{b} \dagger \mathrm{B}}$ & $4.5(0.1)^{\mathrm{ab} \dagger}$ & $4.5(0.1)^{\mathrm{a} \dagger}$ \\
\hline Soil organic $\mathrm{C}\left(\mathrm{kg} \mathrm{C} \mathrm{m}^{-2}\right)$ & $2.6(0.2)$ & $2.7(0.3)^{\mathrm{B}}$ & $2.0(0.3)$ & $1.8(0.2)$ \\
\hline Total $\mathrm{N}\left(\mathrm{g} \mathrm{N} \mathrm{m}^{-2}\right)$ & $182.9(10.8)$ & $186.1(11.0)^{\mathrm{B}}$ & $172.6(23.8)$ & $145.0(13.5)$ \\
\hline $\mathrm{C}: \mathrm{N}$ ratio & $14.3(0.2)^{\mathrm{a}}$ & $13.7(0.8)^{\mathrm{a}}$ & $11.7(0.7)^{\mathrm{b}}$ & $12.5(0.5)^{\mathrm{ab}}$ \\
\hline Effective cation exchange capacity (mmolc kg ${ }^{-1}$ ) & $44.8(5.0)$ & $40.6(7.6)^{\mathrm{B}}$ & $46.0(5.4)$ & $39.5(7.9)$ \\
\hline Base saturation (\%) & $10.6(0.5)^{\mathrm{b} \dagger \mathrm{B}}$ & $16.0(2.2)^{\mathrm{ab} \dagger}$ & $21.1(7.5)^{\mathrm{ab} \dagger}$ & $27.9(5.4)^{\mathrm{a} \dagger}$ \\
\hline Potassium $\left(\mathrm{g} \mathrm{K} \mathrm{m}^{-2}\right)$ & $3.3(0.3)$ & $2.6(0.2)^{\mathrm{B}}$ & $3.4(0.8)$ & $2.1(0.8)$ \\
\hline Sodium $\left(\mathrm{g} \mathrm{Na} \mathrm{m}^{-2}\right)$ & $0.5(0.1)^{\mathrm{cB}}$ & $1.5(0.2)^{\mathrm{bB}}$ & $1.4(0.1)^{b}$ & $3.9(1.1)^{\mathrm{a}}$ \\
\hline Calcium $\left(\mathrm{g} \mathrm{Ca} \mathrm{m}^{-2}\right)$ & $5.5(2.0)$ & $6.9(0.8)^{\mathrm{B} \dagger}$ & $14.5(7.1)$ & $18.5(7.4)$ \\
\hline Magnesium $\left(\mathrm{g} \mathrm{Mg} \mathrm{m}^{-2}\right)$ & $1.8(0.1)$ & $2.0(0.3)^{\mathrm{B}}$ & $3.4(1.4)$ & $1.7(0.9)$ \\
\hline Aluminum $\left(\mathrm{g} \mathrm{Al} \mathrm{m}^{-2}\right)$ & $33.1(3.5)$ & $29.6(6.6)^{\mathrm{B}}$ & $30.7(4.3)$ & $23.5(2.7)$ \\
\hline Iron $\left(\mathrm{g} \mathrm{Fe} \mathrm{m}^{-2}\right)$ & $0.8(0.1)^{\mathrm{a} B}$ & $0.3(0.02)^{\mathrm{bc} \mathrm{B}}$ & $0.3(0.1)^{\mathrm{c}}$ & $0.5(0.02)^{\mathrm{ab}}$ \\
\hline Manganese $\left(\mathrm{g} \mathrm{Mn} \mathrm{m}^{-2}\right)$ & $0.3(0.1)$ & $0.4(0.2)^{\mathrm{B}}$ & $0.8(0.3)$ & $0.5(0.2)$ \\
\hline Bray-extractable phosphorus $\left(\mathrm{g} \mathrm{Pm}^{-2}\right)$ & $0.5(0.1)^{\mathrm{B}}$ & $0.7(0.1)$ & $0.5(0.1)$ & $0.8(0.1)$ \\
\hline Clay at $1.0-1.5 \mathrm{~m}(\%)$ & $33.3(7.6)$ & $42.4(9.9)$ & $46.1(9.9)$ & $43.3(2.8)$ \\
\hline Clay at $1.5-2.0 \mathrm{~m}(\%)$ & $37.3(8.7)$ & $44.5(10.0)$ & $43.4(6.5)$ & $47.6(4.5)$ \\
\hline \multicolumn{5}{|l|}{ Clay Acrisol soil } \\
\hline Bulk density $\left(\mathrm{g} \mathrm{cm}^{-3}\right)$ & $1.0(0.1)$ & $0.8(0.1)^{\mathrm{B}}$ & $0.9(0.1)$ & $0.9(0.1)$ \\
\hline $\mathrm{pH}\left(1: 4 \mathrm{H}_{2} \mathrm{O}\right)$ & $4.2(0.04)^{\mathrm{b}}$ & $4.5(0.04)^{\mathrm{aA}}$ & $4.5(0.1)^{\mathrm{a}}$ & $4.4(0.04)^{\mathrm{a}}$ \\
\hline Soil organic $\mathrm{C}\left(\mathrm{kg} \mathrm{C} \mathrm{m}^{-2}\right)$ & $3.3(0.5)$ & $4.3(0.4)^{\mathrm{A}}$ & $2.8(0.4)$ & $3.5(0.2)$ \\
\hline Total $\mathrm{N}\left(\mathrm{g} \mathrm{N} \mathrm{m}^{-2}\right)$ & $263.4(67.1)$ & $331.4(34.1)^{\mathrm{A}}$ & $198.9(32.5)$ & $260.2(22.6)$ \\
\hline $\mathrm{C}: \mathrm{N}$ ratio & $13.1(1.3)$ & $13.0(0.3)$ & $14.3(0.6)$ & $13.5(0.2)$ \\
\hline Effective cation exchange capacity (mmolc kg ${ }^{-1}$ ) & $94.3(40.8)$ & $124.5(25.5)^{\mathrm{A}}$ & $71.3(22.3)$ & $78.1(8.4)$ \\
\hline Base saturation (\%) & $22.9(5.6)^{\mathrm{A}}$ & $23.2(5.8)$ & $20.1(2.6)$ & $37.5(7.1)$ \\
\hline Potassium $\left(\mathrm{g} \mathrm{K} \mathrm{m}^{-2}\right)$ & $9.4(3.9)$ & $9.6(2.6)^{\mathrm{A}}$ & $4.2(1.1)$ & $4.8(0.9)$ \\
\hline Sodium $\left(\mathrm{g} \mathrm{Na} \mathrm{m}^{-2}\right)$ & $3.6(0.8)^{\mathrm{A}}$ & $4.2(0.2)^{\mathrm{A}}$ & $3.7(1.3)$ & $1.9(1.3)$ \\
\hline Calcium $\left(\mathrm{g} \mathrm{Ca} \mathrm{m}^{-2}\right)$ & $32.3(21.2)$ & $33.3(10.9)^{\mathrm{A} \dagger}$ & $14.7(2.8)$ & $59.1(19.5)$ \\
\hline Magnesium $\left(\mathrm{g} \mathrm{Mg} \mathrm{m}^{-2}\right)$ & $7.3(3.9)$ & $12.0(4.1)^{\mathrm{A}}$ & $4.0(0.9)$ & $3.5(0.8)$ \\
\hline Aluminum $\left(\mathrm{g} \mathrm{Al} \mathrm{m}^{-2}\right)$ & $50.9(22.7)$ & $76.6(15.6)^{\mathrm{A}}$ & $47.2(17.6)$ & $34.4(2.0)$ \\
\hline Iron $\left(\mathrm{g} \mathrm{Fe} \mathrm{m}^{-2}\right)$ & $3.7(1.1)^{\mathrm{aA}}$ & $3.0(0.4)^{\mathrm{a} \mathrm{A}}$ & $2.3(0.6)^{\mathrm{a}}$ & $0.7(0.3)^{\mathrm{b}}$ \\
\hline Manganese $\left(\mathrm{g} \mathrm{Mn} \mathrm{m}^{-2}\right)$ & $4.5(3.1)$ & $2.5(0.7)^{\mathrm{A}}$ & $1.5(0.4)$ & $3.4(1.3)$ \\
\hline Bray-extractable phosphorus $\left(\mathrm{g} \mathrm{Pm}^{-2}\right)$ & $1.4(0.1)^{\mathrm{ab} \mathrm{A}}$ & $0.8(0.1)^{\mathrm{bc}}$ & $0.4(0.04)^{\mathrm{c}}$ & $4.7(1.5)^{\mathrm{a}}$ \\
\hline Clay at $1.0-1.5 \mathrm{~m} \mathrm{( \% )}$ & $39.0(13.0)$ & $62.8(12.6)$ & $40.8(10.3)$ & $62.8(3.7)$ \\
\hline Clay at $1.5-2.0 \mathrm{~m}(\%)$ & $41.3(11.2)$ & $46.6(16.2)$ & $36.5(10.8)$ & $63.3(6.1)$ \\
\hline
\end{tabular}


Table A2. Mean ( \pm SE, $n=4)$ tree density, diameter at breast height $(\mathrm{DBH})$, basal area, height, cumulative fine root mass in the top $1 \mathrm{~m}$ of depth, and the most common tree species with $\mathrm{DBH} \geq 0.10 \mathrm{~m}$ in different land uses within the loam and clay Acrisol soils in Jambi, Sumatra, Indonesia. The vegetation characteristics (e.g., tree density, DBH, basal area, and height) were reported by Kotowska et al. (2015); the five most numerous tree families with $\mathrm{DBH} \geq 0.10 \mathrm{~m}$ are based on Rembold et al. (2017) and Rembold (Katja Rembold, personal communication, 2018). The fine root mass in the top $1 \mathrm{~m}$ of soil depth was measured in our present study. Means of fine root mass followed by different lowercase letters indicate significant differences among land uses within each soil type (one-way ANOVA with Fisher's LSD test at $P \leq 0.05$ and $\dagger$ at $P \leq 0.09$ for marginal significance).

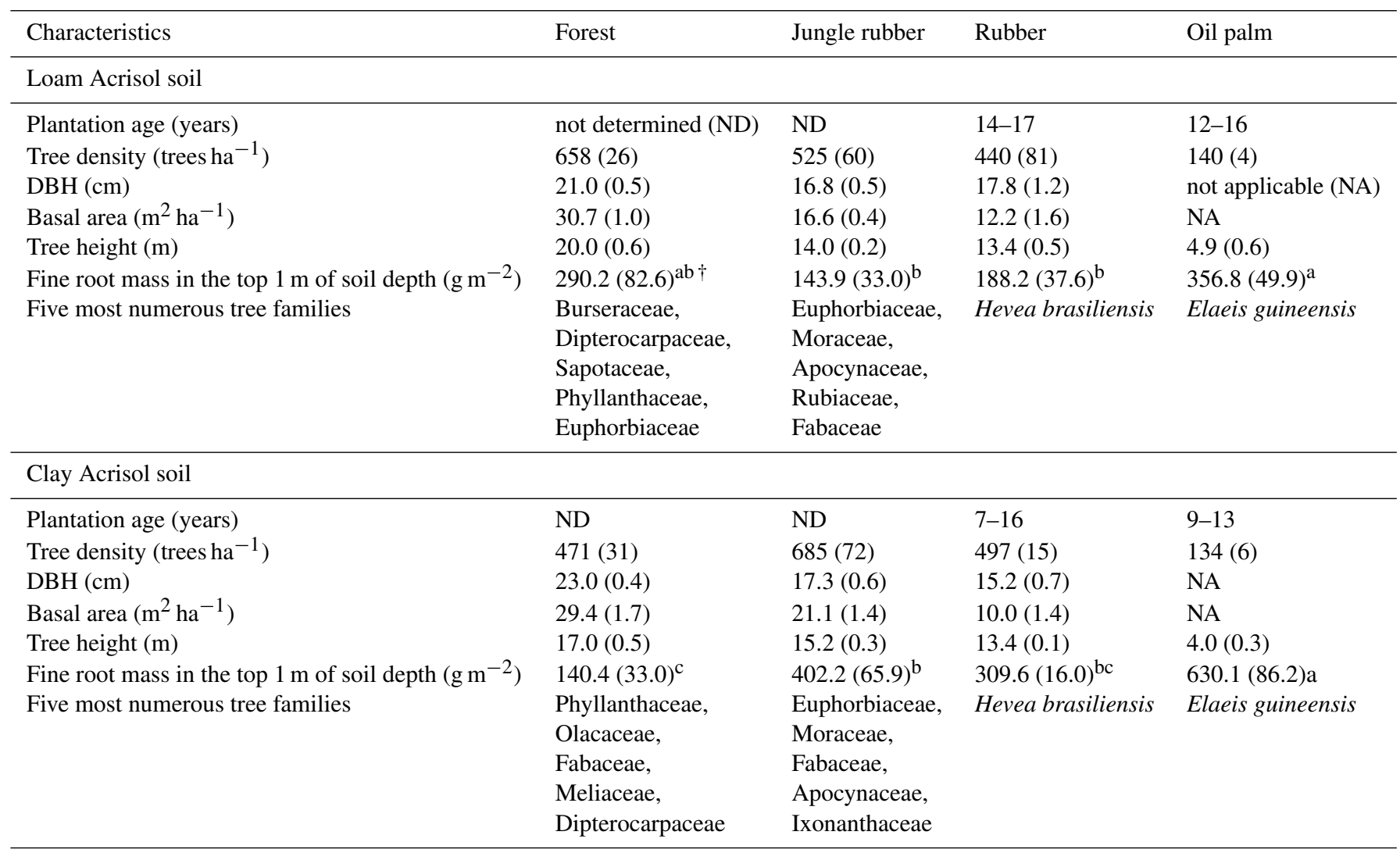


Table A3. Pearson correlations among element concentrations $\left(\mathrm{mg} \mathrm{L}^{-1}\right)$ in soil solutions from a depth of $1.5 \mathrm{~m}$ in different land uses within the loam Acrisol soil in Jambi, Sumatra, Indonesia. Correlations were carried out using monthly averages of four replicate plots per land use $\left(n=12\right.$ monthly measurements in 2013). Elements that had concentrations $<0.03 \mathrm{mg} \mathrm{L}^{-1}$ (total Fe, total Mn, and total P) and total Si that did not show correlation with other elements are not reported below.

\begin{tabular}{|c|c|c|c|c|c|c|c|c|c|c|}
\hline Element & $\mathrm{NH}_{4}^{+}-\mathrm{N}$ & $\mathrm{NO}_{3}^{-} \mathrm{N}$ & DOC & $\mathrm{Na}^{+}$ & $\mathrm{K}^{+}$ & $\mathrm{Ca}^{2+}$ & $\mathrm{Mg}^{2+}$ & Total Al & Total S & $\mathrm{Cl}^{-}$ \\
\hline \multicolumn{11}{|l|}{ Forest } \\
\hline DON & $0.79^{\mathrm{c}}$ & -0.24 & $0.77^{\mathrm{c}}$ & 0.36 & 0.43 & $0.80^{\mathrm{c}}$ & $0.77^{\mathrm{c}}$ & $0.84^{\mathrm{c}}$ & -0.17 & $0.86^{\mathrm{c}}$ \\
\hline $\mathrm{NH}_{4}^{+}-\mathrm{N}$ & & 0.22 & 0.48 & 0.23 & $0.64^{\mathrm{b}}$ & $0.67^{\mathrm{b}}$ & $0.65^{\mathrm{b}}$ & $0.58^{\mathrm{b}}$ & 0.30 & $0.58^{\mathrm{b}}$ \\
\hline $\mathrm{NO}_{3}^{-}-\mathrm{N}$ & & & -0.12 & -0.09 & 0.35 & -0.26 & -0.25 & -0.45 & $0.63^{\mathrm{b}}$ & -0.47 \\
\hline DOC & & & & 0.36 & 0.45 & $0.72^{\mathrm{c}}$ & $0.71^{\mathrm{c}}$ & $0.73^{\mathrm{c}}$ & -0.02 & $0.68^{b}$ \\
\hline $\mathrm{Na}^{+}$ & & & & & $0.58^{\mathrm{b}}$ & $0.53^{\mathrm{a}}$ & 0.46 & 0.34 & 0.23 & 0.45 \\
\hline $\mathrm{K}^{+}$ & & & & & & $0.51^{\mathrm{a}}$ & 0.45 & 0.29 & $0.71^{\mathrm{c}}$ & 0.33 \\
\hline $\mathrm{Ca}^{2+}$ & & & & & & & $0.99^{c}$ & $0.94^{\mathrm{c}}$ & 0.00 & $0.92^{\mathrm{c}}$ \\
\hline $\mathrm{Mg}^{2+}$ & & & & & & & & $0.95^{\mathrm{c}}$ & -0.03 & $0.92^{\mathrm{c}}$ \\
\hline Total Al & & & & & & & & & -0.28 & $0.95^{\mathrm{c}}$ \\
\hline Total S & & & & & & & & & & -0.23 \\
\hline \multicolumn{11}{|c|}{ Jungle rubber } \\
\hline DON & $0.80^{\mathrm{c}}$ & 0.28 & $0.77^{\mathrm{c}}$ & $0.72^{\mathrm{c}}$ & $0.85^{\mathrm{c}}$ & $0.72^{\mathrm{c}}$ & $0.79^{c}$ & 0.30 & $0.60^{\mathrm{b}}$ & $0.68^{\mathrm{b}}$ \\
\hline $\mathrm{NH}_{4}^{+}-\mathrm{N}$ & & 0.32 & $0.73^{\mathrm{c}}$ & 0.35 & $0.77^{\mathrm{c}}$ & $0.53^{\mathrm{a}}$ & $0.67^{\mathrm{b}}$ & $0.55^{\mathrm{b}}$ & 0.17 & $0.79^{\mathrm{c}}$ \\
\hline $\mathrm{NO}_{3}^{-}-\mathrm{N}$ & & & 0.35 & 0.17 & 0.20 & $0.65^{\mathrm{b}}$ & $0.62^{\mathrm{b}}$ & $0.61^{\mathrm{b}}$ & -0.11 & $0.65^{\mathrm{b}}$ \\
\hline DOC & & & & $0.63^{\mathrm{b}}$ & $0.76^{\mathrm{c}}$ & $0.51^{\mathrm{a}}$ & $0.53^{\mathrm{a}}$ & 0.13 & $0.57^{\mathrm{b}}$ & $0.49^{\mathrm{a}}$ \\
\hline $\mathrm{Na}^{+}$ & & & & & $0.80^{\mathrm{c}}$ & $0.58^{\mathrm{b}}$ & $0.55^{\mathrm{b}}$ & -0.18 & $0.93^{\mathrm{c}}$ & 0.29 \\
\hline $\mathrm{K}^{+}$ & & & & & & $0.65^{\mathrm{b}}$ & $0.70^{\mathrm{c}}$ & 0.12 & $0.65^{\mathrm{b}}$ & $0.60^{\mathrm{b}}$ \\
\hline $\mathrm{Ca}^{2+}$ & & & & & & & $0.97^{\mathrm{c}}$ & $0.56^{\mathrm{b}}$ & 0.32 & $0.84^{\mathrm{c}}$ \\
\hline $\mathrm{Mg}^{2+}$ & & & & & & & & $0.65^{\mathrm{b}}$ & 0.27 & $0.93^{\mathrm{c}}$ \\
\hline Total Al & & & & & & & & & -0.47 & $0.85^{\mathrm{c}}$ \\
\hline Total S & & & & & & & & & & -0.02 \\
\hline \multicolumn{11}{|l|}{ Rubber } \\
\hline DON & -0.12 & -0.32 & $0.53^{\mathrm{a}}$ & 0.04 & $0.65^{\mathrm{b}}$ & 0.37 & 0.65 & $0.67^{\mathrm{b}}$ & -0.28 & 0.39 \\
\hline $\mathrm{NH}_{4}^{+}-\mathrm{N}$ & & 0.10 & 0.31 & $0.61^{b}$ & -0.05 & 0.17 & -0.07 & -0.41 & $0.65^{\mathrm{b}}$ & -0.18 \\
\hline $\mathrm{NO}_{3}^{-}-\mathrm{N}$ & & & -0.25 & 0.25 & -0.48 & 0.42 & 0.15 & -0.09 & 0.26 & 0.31 \\
\hline DOC & & & & $0.50^{\mathrm{a}}$ & 0.46 & $0.51^{\mathrm{a}}$ & $0.50^{\mathrm{a}}$ & 0.29 & 0.30 & 0.34 \\
\hline $\mathrm{Na}^{+}$ & & & & & 0.17 & 0.46 & 0.08 & -0.34 & $0.85^{\mathrm{c}}$ & 0.00 \\
\hline $\mathrm{K}^{+}$ & & & & & & 0.24 & $0.55^{\mathrm{b}}$ & $0.54^{\mathrm{a}}$ & -0.15 & 0.38 \\
\hline $\mathrm{Ca}^{2+}$ & & & & & & & $0.81^{\mathrm{c}}$ & 0.40 & 0.27 & $0.72^{\mathrm{c}}$ \\
\hline $\mathrm{Mg}^{2+}$ & & & & & & & & $0.84^{\mathrm{c}}$ & -0.26 & $0.92^{\mathrm{c}}$ \\
\hline Total Al & & & & & & & & & $-0.70^{\mathrm{c}}$ & $0.83^{\mathrm{c}}$ \\
\hline Total S & & & & & & & & & & -0.35 \\
\hline \multicolumn{11}{|c|}{ Oil palm fertilized areas } \\
\hline DON & -0.28 & 0.08 & -0.18 & $-0.57^{b}$ & -0.12 & 0.16 & 0.31 & 0.50 & -0.06 & 0.08 \\
\hline $\mathrm{NH}_{4}^{+}-\mathrm{N}$ & & $0.54^{\mathrm{a}}$ & -0.12 & 0.00 & 0.50 & 0.15 & 0.37 & 0.46 & 0.22 & 0.46 \\
\hline $\mathrm{NO}_{3}^{-}-\mathrm{N}$ & & & -0.12 & 0.14 & -0.02 & -0.49 & 0.00 & $0.63^{\mathrm{b}}$ & -0.38 & 0.10 \\
\hline DOC & & & & -0.22 & 0.08 & 0.02 & 0.29 & -0.17 & 0.40 & -0.47 \\
\hline $\mathrm{Na}^{+}$ & & & & & -0.12 & -0.45 & -0.45 & -0.37 & -0.38 & 0.22 \\
\hline $\mathrm{K}^{+}$ & & & & & & $0.58^{\mathrm{b}}$ & 0.43 & -0.17 & $0.58^{\mathrm{b}}$ & 0.27 \\
\hline $\mathrm{Ca}^{2+}$ & & & & & & & 0.48 & -0.19 & $0.79^{\mathrm{c}}$ & 0.45 \\
\hline $\mathrm{Mg}^{2+}$ & & & & & & & & 0.40 & $0.72^{\mathrm{c}}$ & 0.41 \\
\hline Total Al & & & & & & & & & -0.16 & 0.27 \\
\hline Total S & & & & & & & & & & 0.30 \\
\hline
\end{tabular}

${ }^{\mathrm{a}} P \leq 0.09,{ }^{\mathrm{b}} P \leq 0.05,{ }^{\mathrm{c}} P \leq 0.01$. 
Table A3. Continued.

\begin{tabular}{|c|c|c|c|c|c|c|c|c|c|c|}
\hline Element & $\mathrm{NH}_{4}^{+}-\mathrm{N}$ & $\mathrm{NO}_{3}^{-} \mathrm{N}$ & DOC & $\mathrm{Na}^{+}$ & $\mathrm{K}^{+}$ & $\mathrm{Ca}^{2+}$ & $\mathrm{Mg}^{2+}$ & Total Al & Total S & $\mathrm{Cl}^{-}$ \\
\hline \multicolumn{11}{|c|}{ Oil palm frond-stacked areas } \\
\hline DON & -0.38 & 0.38 & 0.22 & -0.38 & 0.24 & -0.47 & -0.16 & 0.47 & $-0.59^{\mathrm{b}}$ & 0.04 \\
\hline $\mathrm{NH}_{4}^{+}-\mathrm{N}$ & & 0.07 & 0.23 & 0.40 & 0.25 & 0.04 & 0.08 & -0.17 & 0.42 & 0.06 \\
\hline $\mathrm{NO}_{3}^{-}-\mathrm{N}$ & & & $0.61^{\mathrm{b}}$ & 0.12 & $0.56^{\mathrm{b}}$ & -0.26 & -0.21 & 0.11 & 0.20 & 0.02 \\
\hline DOC & & & & -0.10 & $0.57^{b}$ & -0.38 & $-0.55^{\mathrm{b}}$ & -0.28 & 0.22 & -0.42 \\
\hline $\mathrm{Na}^{+}$ & & & & & 0.09 & 0.23 & 0.22 & -0.35 & $0.61^{\mathrm{b}}$ & 0.09 \\
\hline $\mathrm{K}^{+}$ & & & & & & -0.27 & -0.21 & -0.07 & 0.29 & -0.06 \\
\hline $\mathrm{Ca}^{2+}$ & & & & & & & $0.83^{\mathrm{c}}$ & 0.30 & -0.15 & $0.72^{\mathrm{c}}$ \\
\hline $\mathrm{Mg}^{2+}$ & & & & & & & & $0.63^{\mathrm{b}}$ & -0.41 & $0.95^{\mathrm{c}}$ \\
\hline Total Al & & & & & & & & & $-0.81^{\mathrm{c}}$ & $0.79^{c}$ \\
\hline Total S & & & & & & & & & & -0.48 \\
\hline
\end{tabular}

${ }^{\mathrm{a}} P \leq 0.09,{ }^{\mathrm{b}} P \leq 0.05,{ }^{\mathrm{c}} P \leq 0.01$. 
Table A4. Pearson correlations among element concentrations $\left(\mathrm{mg} \mathrm{L}^{-1}\right)$ in soil solutions from a depth of $1.5 \mathrm{~m}$ in different land uses within the clay Acrisol soil in Jambi, Sumatra, Indonesia. Correlations were carried out using monthly averages of four replicate plots per land use ( $n=12$ monthly measurements in 2013). Elements that had concentrations $<0.03 \mathrm{mg} \mathrm{L}^{-1}$ (total Fe, total Mn, and total P) and total Si that did not show correlation with other elements are not reported below.

\begin{tabular}{|c|c|c|c|c|c|c|c|c|c|c|}
\hline Element & $\mathrm{NH}_{4}^{+}-\mathrm{N}$ & $\mathrm{NO}_{3}^{-}-\mathrm{N}$ & DOC & $\mathrm{Na}^{+}$ & $\mathrm{K}^{+}$ & $\mathrm{Ca}^{2+}$ & $\mathrm{Mg}^{2+}$ & Total Al & Total S & $\mathrm{Cl}^{-}$ \\
\hline \multicolumn{11}{|l|}{ Forest } \\
\hline DON & 0.10 & -0.39 & $0.57^{\mathrm{b}}$ & 0.32 & $0.53^{\mathrm{a}}$ & 0.17 & 0.20 & -0.28 & 0.25 & -0.20 \\
\hline $\mathrm{NH}_{4}^{+}-\mathrm{N}$ & & -0.48 & $0.81^{\mathrm{c}}$ & $0.63^{\mathrm{b}}$ & 0.23 & $0.51^{\mathrm{a}}$ & 0.28 & -0.11 & -0.27 & 0.09 \\
\hline $\mathrm{NO}_{3}^{-}-\mathrm{N}$ & & & -0.48 & -0.24 & -0.18 & -0.05 & -0.03 & 0.36 & 0.12 & 0.37 \\
\hline DOC & & & & $0.66^{\mathrm{b}}$ & 0.41 & 0.48 & 0.31 & -0.25 & -0.15 & -0.06 \\
\hline $\mathrm{Na}^{+}$ & & & & & $0.69^{b}$ & $0.52^{\mathrm{a}}$ & $0.54^{\mathrm{a}}$ & -0.22 & -0.24 & -0.10 \\
\hline $\mathrm{K}^{+}$ & & & & & & $0.74^{\mathrm{c}}$ & $0.88^{\mathrm{c}}$ & 0.22 & -0.17 & 0.26 \\
\hline $\mathrm{Ca}^{2+}$ & & & & & & & $0.93^{\mathrm{c}}$ & $0.54^{\mathrm{a}}$ & -0.29 & $0.70^{\mathrm{c}}$ \\
\hline $\mathrm{Mg}^{2+}$ & & & & & & & & $0.52^{\mathrm{a}}$ & -0.34 & $0.59^{\mathrm{b}}$ \\
\hline Total Al & & & & & & & & & -0.15 & $0.94^{\mathrm{c}}$ \\
\hline Total S & & & & & & & & & & -0.10 \\
\hline \multicolumn{11}{|c|}{ Jungle rubber } \\
\hline DON & 0.23 & $0.55^{\mathrm{b}}$ & $0.58^{\mathrm{b}}$ & 0.19 & $0.69^{c}$ & $0.50^{\mathrm{a}}$ & $0.63^{\mathrm{b}}$ & $0.70^{\mathrm{c}}$ & -0.22 & $0.49^{\mathrm{a}}$ \\
\hline $\mathrm{NH}_{4}^{+}-\mathrm{N}$ & & 0.01 & 0.36 & 0.35 & 0.35 & 0.29 & 0.29 & 0.16 & 0.31 & 0.18 \\
\hline $\mathrm{NO}_{3}^{-}-\mathrm{N}$ & & & 0.32 & 0.30 & $0.49^{\mathrm{a}}$ & $0.51^{\mathrm{a}}$ & $0.50^{\mathrm{a}}$ & 0.35 & 0.13 & 0.42 \\
\hline DOC & & & & -0.24 & 0.11 & -0.14 & -0.05 & 0.29 & 0.06 & -0.20 \\
\hline $\mathrm{Na}^{+}$ & & & & & $0.68^{\mathrm{c}}$ & $0.84^{\mathrm{c}}$ & $0.73^{\mathrm{c}}$ & 0.01 & $0.52^{\mathrm{a}}$ & $0.66^{\mathrm{b}}$ \\
\hline $\mathrm{K}^{+}$ & & & & & & $0.87^{\mathrm{c}}$ & $0.93^{\mathrm{c}}$ & $0.63^{b}$ & 0.09 & $0.84^{\mathrm{c}}$ \\
\hline $\mathrm{Ca}^{2+}$ & & & & & & & $0.97^{\mathrm{c}}$ & $0.50^{\mathrm{a}}$ & 0.09 & $0.95^{\mathrm{c}}$ \\
\hline $\mathrm{Mg}^{2+}$ & & & & & & & & $0.66^{\mathrm{b}}$ & -0.04 & $0.97^{\mathrm{c}}$ \\
\hline Total Al & & & & & & & & & $-0.62^{b}$ & $0.68^{\mathrm{b}}$ \\
\hline Total S & & & & & & & & & & -0.18 \\
\hline \multicolumn{11}{|l|}{ Rubber } \\
\hline DON & -0.20 & -0.18 & 0.21 & -0.29 & 0.41 & 0.40 & $0.55^{\mathrm{b}}$ & $0.65^{\mathrm{b}}$ & $-0.57^{\mathrm{b}}$ & 0.48 \\
\hline $\mathrm{NH}_{4}^{+}-\mathrm{N}$ & & 0.22 & $0.81^{\mathrm{c}}$ & $0.85^{\mathrm{c}}$ & 0.47 & 0.19 & 0.10 & -0.20 & $0.52^{\mathrm{a}}$ & -0.06 \\
\hline $\mathrm{NO}_{3}^{-}-\mathrm{N}$ & & & -0.07 & -0.16 & -0.44 & $-0.68^{b}$ & $-0.60^{\mathrm{b}}$ & -0.38 & 0.05 & $-0.63^{\mathrm{b}}$ \\
\hline DOC & & & & $0.79^{\mathrm{c}}$ & $0.71^{\mathrm{c}}$ & $0.54^{\mathrm{a}}$ & 0.45 & 0.20 & 0.43 & 0.30 \\
\hline $\mathrm{Na}^{+}$ & & & & & $0.61^{\mathrm{b}}$ & 0.38 & 0.21 & -0.15 & $0.65^{b}$ & 0.07 \\
\hline $\mathrm{K}^{+}$ & & & & & & $0.67^{\mathrm{b}}$ & $0.66^{\mathrm{b}}$ & 0.46 & 0.08 & $0.64^{\mathrm{b}}$ \\
\hline $\mathrm{Ca}^{2+}$ & & & & & & & $0.93^{\mathrm{c}}$ & $0.73^{\mathrm{c}}$ & -0.16 & $0.83^{\mathrm{c}}$ \\
\hline $\mathrm{Mg}^{2+}$ & & & & & & & & $0.88^{\mathrm{c}}$ & -0.39 & $0.93^{\mathrm{c}}$ \\
\hline Total Al & & & & & & & & & $-0.58^{\mathrm{b}}$ & $0.89^{\mathrm{c}}$ \\
\hline Total S & & & & & & & & & & -0.40 \\
\hline \multicolumn{11}{|c|}{ Oil palm fertilized areas } \\
\hline DON & 0.02 & -0.09 & 0.49 & $0.70^{\mathrm{b}}$ & $0.69^{b}$ & $0.67^{b}$ & 0.42 & 0.45 & $0.54^{\mathrm{a}}$ & $0.63^{b}$ \\
\hline $\mathrm{NH}_{4}^{+}-\mathrm{N}$ & & 0.08 & 0.15 & 0.39 & 0.37 & 0.16 & 0.06 & 0.06 & 0.46 & -0.01 \\
\hline $\mathrm{NO}_{3}^{-}-\mathrm{N}$ & & & -0.18 & 0.03 & 0.46 & $0.51^{\mathrm{a}}$ & -0.01 & 0.19 & 0.33 & -0.49 \\
\hline DOC & & & & $0.52^{\mathrm{a}}$ & $0.66^{\mathrm{b}}$ & $0.56^{\mathrm{a}}$ & 0.50 & $0.56^{\mathrm{a}}$ & 0.25 & $0.70^{\mathrm{b}}$ \\
\hline $\mathrm{Na}^{+}$ & & & & & $0.61^{\mathrm{b}}$ & $0.61^{b}$ & 0.29 & 0.21 & $0.75^{\mathrm{c}}$ & $0.55^{\mathrm{a}}$ \\
\hline $\mathrm{K}^{+}$ & & & & & & $0.85^{\mathrm{c}}$ & $0.74^{\mathrm{c}}$ & $0.78^{\mathrm{c}}$ & $0.52^{\mathrm{a}}$ & $0.59^{\mathrm{b}}$ \\
\hline $\mathrm{Ca}^{2+}$ & & & & & & & $0.81^{\mathrm{c}}$ & $0.74^{\mathrm{c}}$ & $0.69^{\mathrm{b}}$ & $0.64^{\mathrm{b}}$ \\
\hline $\mathrm{Mg}^{2+}$ & & & & & & & & $0.95^{\mathrm{c}}$ & 0.26 & $0.74^{\mathrm{c}}$ \\
\hline Total Al & & & & & & & & & 0.15 & $0.75^{\mathrm{c}}$ \\
\hline Total S & & & & & & & & & & 0.26 \\
\hline
\end{tabular}

${ }^{\mathrm{a}} P \leq 0.09,{ }^{\mathrm{b}} P \leq 0.05,{ }^{\mathrm{c}} P \leq 0.01$. 
Table A4. Continued.

\begin{tabular}{|c|c|c|c|c|c|c|c|c|c|c|}
\hline Element & $\mathrm{NH}_{4}^{+}-\mathrm{N}$ & $\mathrm{NO}_{3}^{-}-\mathrm{N}$ & DOC & $\mathrm{Na}^{+}$ & $\mathrm{K}^{+}$ & $\mathrm{Ca}^{2+}$ & $\mathrm{Mg}^{2+}$ & Total Al & Total S & $\mathrm{Cl}^{-}$ \\
\hline \multicolumn{11}{|c|}{ Oil palm frond-stacked areas } \\
\hline DON & 0.19 & 0.34 & 0.15 & $0.49^{\mathrm{a}}$ & 0.47 & $0.51^{\mathrm{a}}$ & 0.23 & 0.29 & 0.28 & 0.36 \\
\hline $\mathrm{NH}_{4}^{+}-\mathrm{N}$ & & -0.07 & 0.27 & 0.21 & 0.38 & 0.11 & 0.06 & 0.07 & 0.13 & 0.09 \\
\hline $\mathrm{NO}_{3}^{-}-\mathrm{N}$ & & & -0.28 & 0.24 & 0.32 & 0.13 & -0.13 & 0.09 & $0.56^{\mathrm{b}}$ & -0.05 \\
\hline DOC & & & & 0.09 & 0.23 & 0.25 & 0.45 & 0.02 & -0.46 & 0.19 \\
\hline $\mathrm{Na}^{+}$ & & & & & $0.91^{\mathrm{c}}$ & $0.94^{\mathrm{c}}$ & $0.76^{\mathrm{c}}$ & $0.91^{\mathrm{c}}$ & 0.33 & $0.89^{c}$ \\
\hline $\mathrm{K}^{+}$ & & & & & & $0.88^{c}$ & $0.74^{\mathrm{c}}$ & $0.80^{\mathrm{c}}$ & 0.21 & $0.79^{c}$ \\
\hline $\mathrm{Ca}^{2+}$ & & & & & & & $0.90^{\mathrm{c}}$ & $0.91^{\mathrm{c}}$ & 0.10 & $0.95^{\mathrm{c}}$ \\
\hline $\mathrm{Mg}^{2+}$ & & & & & & & & $0.81^{\mathrm{c}}$ & -0.28 & $0.93^{\mathrm{c}}$ \\
\hline Total Al & & & & & & & & & 0.16 & $0.92^{\mathrm{c}}$ \\
\hline Total S & & & & & & & & & & -0.06 \\
\hline
\end{tabular}

${ }^{\mathrm{a}} P \leq 0.09,{ }^{\mathrm{b}} P \leq 0.05,{ }^{\mathrm{c}} P \leq 0.01$. 
Appendix B: Fine root biomass and soil water model validation

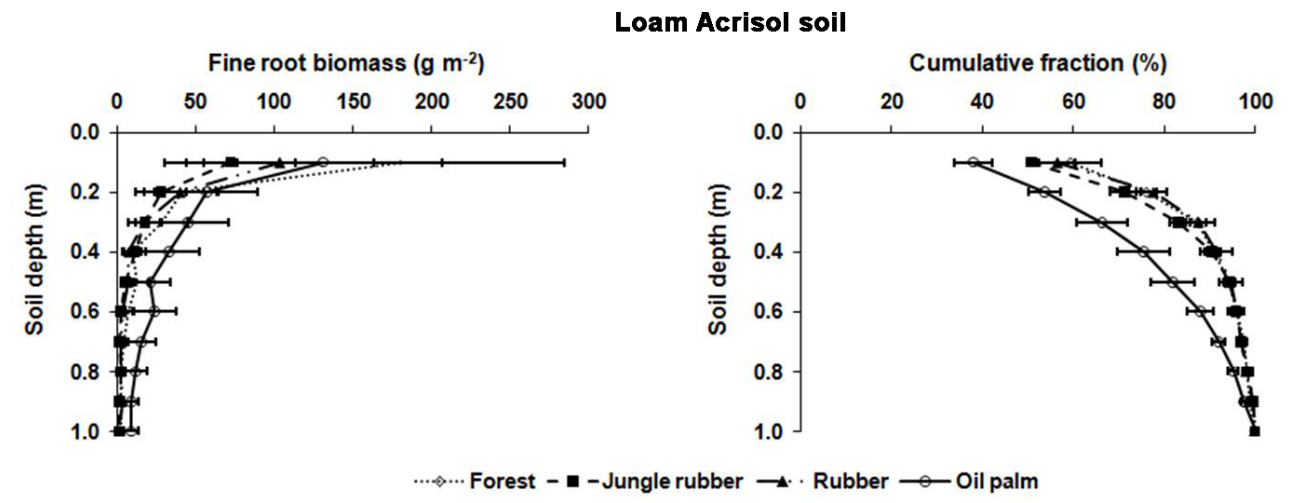

Clay Acrisol soil

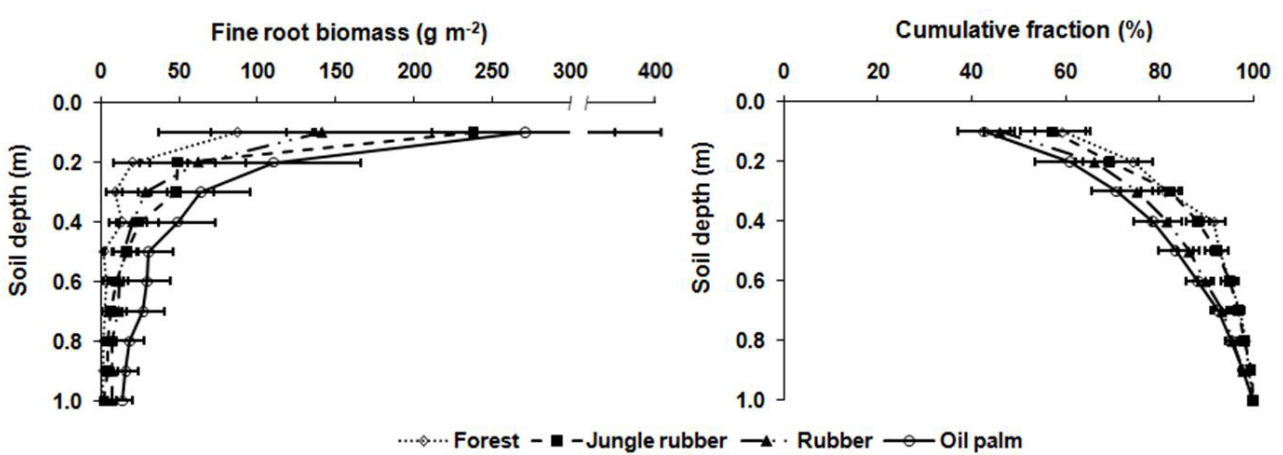

Figure B1. Fine root biomass $\left(\mathrm{g} \mathrm{m}^{-2}\right)$ and distribution $(\%)$ down to a depth of $1 \mathrm{~m}$ in different land uses within the loam and clay Acrisol soils in Jambi, Sumatra, Indonesia. The root measurement was conducted in each replicate plot by digging a pit $(1 \mathrm{~m} \times 1.5 \mathrm{~m} \times 2 \mathrm{~m}$ of depth) at a distance of $2.5 \mathrm{~m}$ from an oil palm or a tree with a diameter at breast height of $\geq 10 \mathrm{~cm}$. Root masses were sampled using a metal block $(20 \mathrm{~cm} \times 20 \mathrm{~cm} \times 10 \mathrm{~cm})$ at a depth interval of $10 \mathrm{~cm}$ from the top down to $1 \mathrm{~m}$. Roots were carefully separated from the soil by washing over a $2 \mathrm{~mm}$ mesh screen and the fine roots were collected in a basin placed underneath the mesh screen. The roots were categorized into fine roots ( $\leq 2 \mathrm{~mm}$ diameter) and coarse roots $(>2 \mathrm{~mm}$ diameter $)$, dried in an oven at $70^{\circ} \mathrm{C}$ for 5 days, and weighed. 


\section{Loam Acrisol soil}
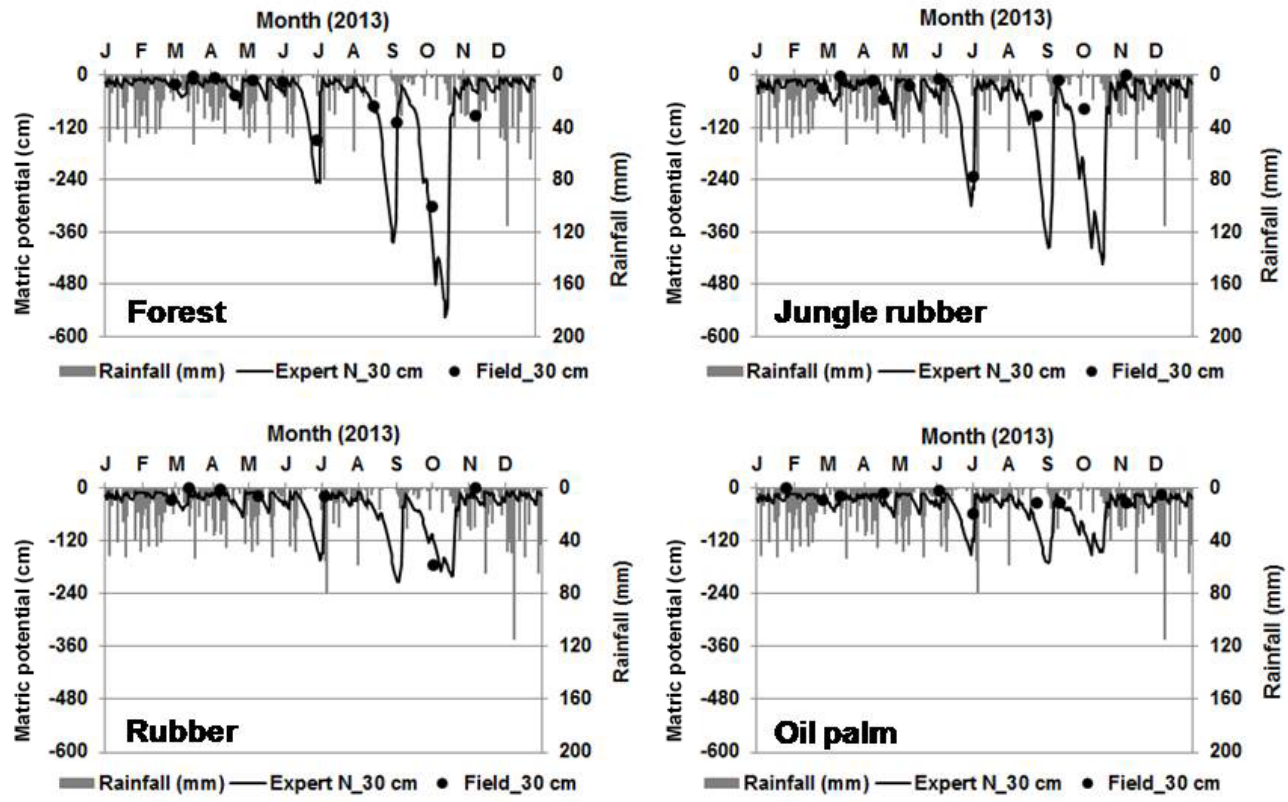

\section{Clay Acrisol soil}
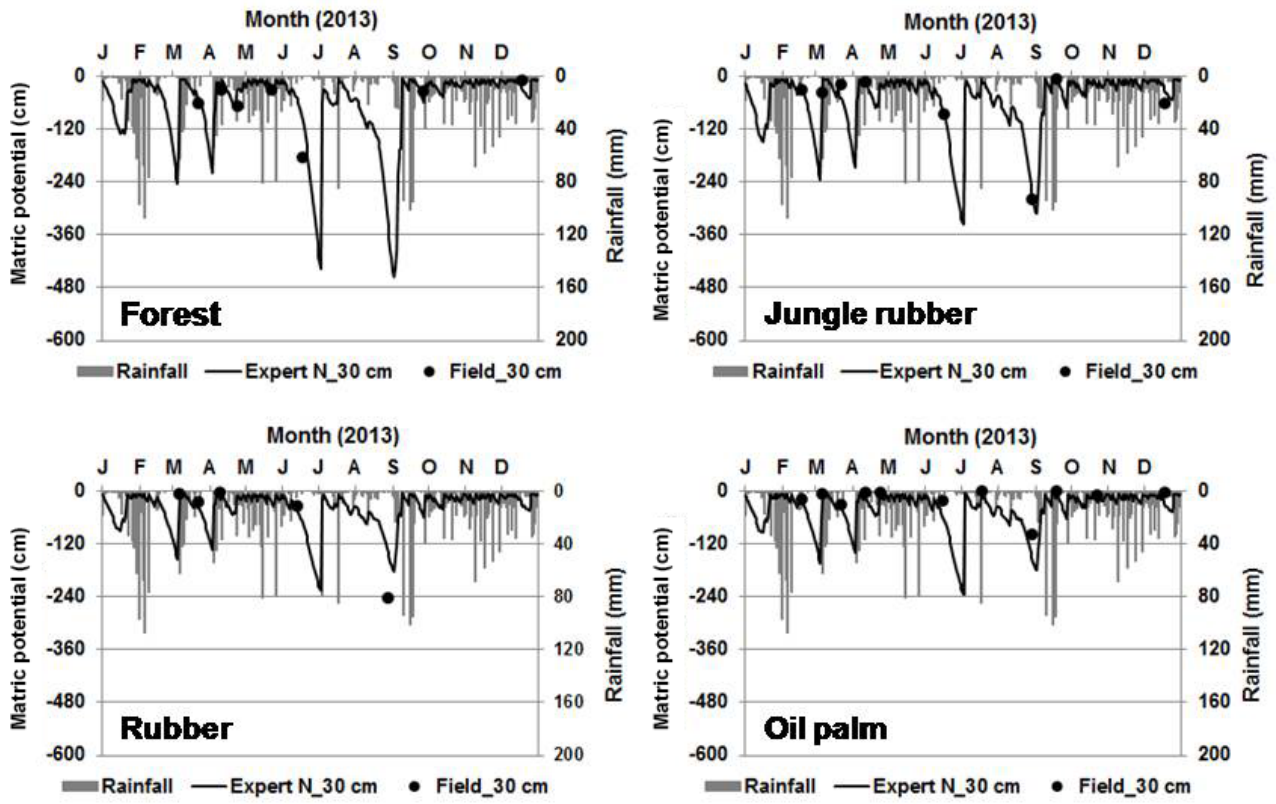

Figure B2. Validation between Expert-N-modeled and field-measured matric potential at a depth of $0.3 \mathrm{~m}$ in different land uses within the loam and clay Acrisol soils in Jambi, Sumatra, Indonesia. 
Author contributions. SK, MDC, EV, and SRU conceived and designed the research. SK carried out field measurements. MDC, EV, and SRU supported the field research. SK and HSB modeled the water budget with the Expert-N water module. SK, MDC, and EV analyzed the data. SK, MDC, ALM, OvS, and EV wrote the paper.

Competing interests. The authors declare that they have no conflict of interest.

Acknowledgements. This study was funded by the Deutsche Forschungsgemeinschaft (DFG) as part of subproject A05 (SFB 990/2) in the Collaborative Research Center 990 (EFForTS). Kurniawan received a postgraduate scholarship from the Indonesian Directorate General of Higher Education. We thank the village leaders, smallholders, PT REKI, and Bukit Duabelas National Park for fruitful collaboration. We are especially grateful to our Indonesian assistants and the rangers of the forest areas. We acknowledge the Indonesian Meteorological, Climatological and Geophysical Agency and the subprojects A03 and B06 for data sharing. We also thank Andrea Bauer, Dirk Böttger, Martina Knaust, and Kerstin Langs for their assistance. This study was conducted using the research permits 215/SIP/FRP/SM/VI/2012 and 44/EXT/SIP/FRP/SM/V/2013 and the collection permits 2703/IPH.1/KS.02/XI/2012 and S.13/KKH-2/2013 recommended by RISTEK and LIPI and issued by PHKA, Indonesia.

This open-access publication was funded

by the University of Göttingen.

Edited by: Frank Hagedorn

Reviewed by: Yit Arn Teh and Kazumichi Fujii

\section{References}

Allen, K., Corre, M. D., Tjoa, A., and Veldkamp, E.: Soil nitrogencycling responses to conversion of lowland forests to oil palm and rubber plantations in Sumatra, Indonesia, PLoS ONE, 10, e0133325, https://doi.org/10.1371/journal.pone.0133325, 2015.

Allen, K., Corre, M. D., Kurniawan, S., Utami, S. R., and Veldkamp, E.: Spatial variability surpasses land-use change effects on soil biochemical properties of converted lowland landscapes in Sumatra, Indonesia, Geoderma, 284, 42-50, https://doi.org/10.1016/j.geoderma.2016.08.010, 2016.

Anuar, A. R., Goh, K. J., Heoh, T. B., and Ahmed, O. H.: Spatial variability of soil inorganic $\mathrm{N}$ in a mature oil palm plantation in Sabah, Malaysia, Am. J. Appl. Sci., 5, 1239-1246, 2008.

Balasubramanian, R., Victor, T., and Begum, R.: Impact of biomass burning on rainwater acidity and composition in Singapore, J. Geophys. Res.-Biogeo., 104, 26881-26890, 1999.

Banabas, M., Turner, M. A., Scotter, D. R., and Nelson, P. N.: Losses of nitrogen fertiliser under oil palm in Papua New Guinea: 1. Water balance, and nitrogen in soil solution and runoff, Aust. J. Soil Res., 46, 332-339, https://doi.org/10.1071/SR07171, 2008.

Bragazza, L., Freeman, C., Jones, T., Rydin, H., Limpens, J., Fenner, N., Ellis, T., Gerdol, R., Hájek, M., Hájek, T., Iacumin, P., Kutnar, L., Tahvanainen, T., and Toberman, H.:
Atmospheric nitrogen deposition promotes carbon loss from peat bogs, P. Natl. Acad. Sci. USA, 103, 19386-19389, https://doi.org/10.1073/pnas.0606629104, 2006.

Clough, Y., Krishna, V. V., Corre, M. D., Darras, K., Denmead, L. H., Meijide, A., Moser, S., Musshoff, O., Steinebach, S., Veldkamp, E., Allen, K., Barnes, A., Breidenbach, N., Brose, U., Buchori, D., Daniel, R., Finkeldey, R., Harahap, I., Hertel, D., Holtkamp, A. M., Hörandl, E., Irawan, B., Jaya, I. N. S., Jochum, M., Klarner, B., Knohl, A., Kotowska, M. M., Krashevska, V., Kreft, H., Kurniawan, S., Leuschner, C., Maraun, M., Melati, D. N., Opfermann, N., Pérez-Cruzado, C., Prabowo, W. E., Rembold, K., Rizali, A., Rubiana, R., Schneider, D., Tjitrosoedirdjo, S. S., Tjoa, A., Tscharntke, T., and Scheu, S.: Land-use choices follow profitability at the expense of ecological functions in Indonesian smallholder landscapes, Nat. Commun., 7, 13137, https://doi.org/10.1038/ncomms13137, 2016.

Comte, I., Colin, F., Grünberger, O., Follain, S., Whalen, J. K., and Caliman, J. P.: Landscape-scale assessment of soil response to long-term organic and mineral fertilizer application in an industrial oil palm plantation, Indonesia, Agric. Ecosyst. Environ., 169, 58-68, https://doi.org/10.1016/j.agee.2013.02.010, 2013.

Corre, M. D., Dechert, G., and Veldkamp, E.: Soil nitrogen cycling following montane forest conversion in Central Sulawesi, Indonesia, Soil Sci. Soc. Am. J., 70, 359-366, https://doi.org/10.2136/sssaj2005.0061, 2006.

Corre, M. D., Veldkamp, E., Arnold, J., and Wright, S. J.: Impact of elevated $\mathrm{N}$ input on soil $\mathrm{N}$ cycling and losses in lowland and montane forests in Panama, Ecology, 91, 1715-1729, https://doi.org/10.1890/09-0274.1, 2010.

Crawley, M. J.: The R book, John Wiley and Sons Limited, Chichester, UK, 2009.

Davidson, E. A., de Carvalho, C. J. R., Figueira, A. M., Ishida, F. Y., Ometto, J. P. H. B., Nardoto, G. B., Saba, R. T., Hayashi, S. N., Leal, E. C., Vieira, I. C. G., and Martinelli, L. A.: Recuperation of nitrogen cycling in Amazonian forests following agricultural abandonment, Nature, 447, 995-998, https://doi.org/10.1038/nature05900, 2007.

Dechert, G., Veldkamp, E., and Anas, I.: Is soil degradation unrelated to deforestation? Examining soil parameters of land use systems in upland Central Sulawesi, Indonesia, Plant Soil, 265, 197-209, https://doi.org/10.1007/s11104-005-0885-8, 2004.

Dechert, G., Veldkamp, E., and Brumme, R.: Are partial nutrient balances suitable to evaluate nutrient sustainability of landuse systems? Results from a case study in Central Sulawesi, Indonesia, Nutri. Cycl. Agroecosyst., 72, 201-212, https://doi.org/10.1007/s10705-005-1546-2, 2005.

DGEC (Directorate General of Estate Crops): Tree crop estate statistics of Indonesia 2015-2017: Palm oil and rubber, Indonesian Ministry of Agriculture, available at: http://ditjenbun.pertanian.go.id/tinymcpuk/gambar/file/statistik/ 2017/Kelapa-Sawit-2015-2017.pdf (last access: 31 January 2018), 2017.

Eklund, T. J., McDowell, W. H., and Pringle, C. M.: Seasonal variation of tropical precipitation chemistry: La Selva, Costa Rica, Atmos. Environ., 31, 3903-3910, https://doi.org/10.1016/S13522310(97)00246-X, 1997.

FAO (Food and Agricultural Organization): Global Forest Resources Assessment 2010, Rome, 2010. 
FAO, IIASA, ISRIC, ISS-CAS, and JRC: Harmonized World Soil Database (version 1.2), FAO, Rome, Italy \& IIASA, Laxenburg, Austria, http://www.fao.org/soils-portal/soil-survey/ soil-maps-and-databases/harmonized-world-soil-database-v12/ en/ (last access: 9 November 2017), 2012.

Fujii, K., Funakawa, S., Hayakawa, C., Sukartiningsih, and Kosaki, T.: Quantification of proton budgets in soils of cropland and adjacent forest in Thailand and Indonesia, Plant Soil, 316, 241-255, https://doi.org/10.1007/s11104-008-9776-0, 2009.

Goh, K. J., Härdter, R., and Fairhurst, T.: Fertilizing for maximum return, in: Oil Palm: Management for Large and Sustainable Yields, edited by: Fairhurst, T. and Härdter, R., PPI/PPIC and IPI, Singapore, 279-306, 2003.

Hassler, E., Corre, M. D., Tjoa, A., Damris, M., Utami, S. R., and Veldkamp, E.: Soil fertility controls soil-atmosphere carbon dioxide and methane fluxes in a tropical landscape converted from lowland forest to rubber and oil palm plantations, Biogeosciences, 12, 5831-5852, https://doi.org/10.5194/bg-125831-2015, 2015.

Hassler, E., Corre, M. D., Kurniawan, S., and Veldkamp, E.: Soil nitrogen oxide fluxes from lowland forests converted to smallholder rubber and oil palm plantations in Sumatra, Indonesia, Biogeosciences, 14, 2781-2798, https://doi.org/10.5194/bg-142781-2017, 2017.

Hedin, L. O., Vitousek, P. M., and Matson, P. A.: Nutrient losses over four million years of tropical forest development, Ecology, 84, 2231-2255, https://doi.org/10.1890/02-4066, 2003.

Hillel, D: Introduction to Soil Physics, 107-114, Academic Press, California, USA, 1982.

Hoeft, I., Keuter, A., Quiñones, C. M., Schmidt-Walter, P., Veldkamp, E., and Corre, M. D.: Nitrogen retention efficiency and nitrogen losses of a managed and phytodiverse temperate grassland, Basic Appl. Ecol., 15, 207-218, https://doi.org/10.1016/j.baae.2014.04.001, 2014.

Kaufmann, J. B., Cummings, D. L., Ward, D. E., and Babbitt, R.: Fire in the Brazilian Amazon: 1. Biomass, nutrient pools, and losses in slashed primary forests, Oecologia, 104, 397-408, https://doi.org/10.1007/BF00341336, 1995.

Klinge, R., Martins, A. A. R., Mackensen, J., and Fölster, H.: Element loss on rain forest conversion in East Amazonia: comparison of balances of stores and fluxes, Biogeochemistry, 69, 63-82, https://doi.org/10.1023/B:BIOG.0000031040.38388.9b, 2004.

Kotowska, M. M., Leuschner, C., Triadiati, T., Meriem, S., and Hertel, D.: Quantifying above- and belowground biomass carbon loss with forest conversion in tropical lowlands of Sumatra (Indonesia), Glob. Change Biol., 21, 3620-3634, https://doi.org/10.1111/gcb.12979, 2015.

Kurniawan, S.: Conversion of lowland forests to rubber and oil palm plantations changes nutrient leaching and nutrient retention efficiency in highly weathered soils of Sumatra, Indonesia, University of Goettingen, Germany, Doctoral thesis, available at: http://hdl.handle.net/11858/00-1735-0000-0028-8706-8 (last access: 25 May 2016), 2016.

Lehman, J. and Schroth, G.: Nutrient leaching, in: Trees, Crops and Soil Fertility: Concepts and Research Methods, edited by: Schroth, G., and Sinclair, F. L., CABI Publishing, Wallinford, UK, 151-166, 2002.

Luskin, M. S., Christina, E. D., Kelly, L. C., and Potts, M. D.: Modern hunting practices and wild meat trade in the oil palm plantation-dominated landscapes of Sumatra, Indonesia, Hum. Ecol., 42, 35-45, https://doi.org/10.1007/s10745-013-9606-8, 2013.

Mackensen, J., Hölscher, D., Klinge, R., and Fölster, H.: Nutrient transfer to the atmosphere by burning of debris in Eastern Amazonia, For. Ecol. Manage., 86, 121-128, https://doi.org/10.1016/S0378-1127(96)03790-5, 1996.

Margono, B. A., Turubanova, S., Zhuravleva, I., Potapov, P., Tyukavina, A., and Baccini, A.: Mapping and monitoring deforestation and forest degradation in Sumatra (Indonesia) using Landsat time series data sets from 1990 to 2010, Environ. Res Lett., 7, 1-16, https://doi.org/10.1088/1748-9326/7/3/034010, 2012.

Markewitz, D., Davidson, E., Figueiredo, R., Victoria, R., and Krusche, A.: Control of cation concentrations in stream waters by surface soil processes in an Amazonian watershed, Nature, 410, 802-805, https://doi.org/10.1038/35071052, 2001.

Mualem, Y.: New model for predicting hydraulic conductivity of unsaturated porous-media, Water Resour. Res., 12, 513-522, https://doi.org/10.1029/WR012i003p00513, 1976.

Ngoze, S., Riha, S., Lehmann, J., Verchot, L., Kinyangi, J., Mbugua, D., and Pell A.: Nutrient constraints to tropical agroecosystem productivity in long-term degrading soils, Glob. Change Biol., 14, 2810-2822, https://doi.org/10.1111/j.13652486.2008.01698.x, 2008.

Niu, F., Röll, A., Hardanto, A., Meijide, A., Köhler, M., Hendrayanto, and Hölscher, D.: Oil palm water use: calibration of a sap flux method and a field measurement scheme, Tree Physiol., 35, 563-573, https://doi.org/10.1093/treephys/tpv013, 2015.

Ohta, S., Effendi, S., Tanaka, N., and Miura, S.: Ultisols of lowland dipterocarp forest in East Kalimantan, Indonesia, III, Clay minerals, free oxides, and exchangeable cations, Soil Sci. Plant Nutr., 39, 1-12, https://doi.org/10.1080/00380768.1993.10416969, 1993.

Omoti, U., Ataga, D. O., and Isenmila, A. E.: Leaching losses of nutrients in oil palm plantations determined by tension lysimeters, Plant Soil, 73, 365-376, https://doi.org/10.1007/BF02184313, 1983.

Ponette-González, A. G., Curran, L. M., Pittman, A. M., Carlson, K. M., Steele, B. G., Ratnasari, D., Mujiman, and Weathers, K. C.: Biomass burning drives atmospheric nutrient redistribution within forested peatlands in Borneo, Environ. Res. Lett., 11, 085003, https://doi.org/10.1088/1748-9326/11/8/085003, 2016.

Priesack, E.: Expert-N model library documentation, Institute of Soil Ecology, National Research Center for Environment and Health, Neuherberg, Germany, 2005.

R Development Core Team: R: A language and environment for statistical computing, R Foundation for Statistical Computing, Vienna, Austria, available at: http://www.R-project.org (last access: 18 November 2016), 2013.

Rembold, K., Mangopo, H., Tjitrosoedirdjo, S. S., and Kreft, H.: Plant diversity, forest dependency, and alien plant invasions in tropical agricultural landscapes, Biodivers. Conserv., 213, 234 242, https://doi.org/10.1016/j.biocon.2017.07.020, 2017.

Rist, L., Feintrenie, L., and Levang, P.: The livelihood impacts of oil palm: smallholders in Indonesia, Biodivers. Conserv., 19, 1009 1024, https://doi.org/10.1007/s10531-010-9815-z, 2010.

Sahner, J., Budi, S. W., Barus, H., Edy, N., Meyer, M., Corre, M. D., and Polle, A.: Degradation of root community traits as in- 
dicator for transformation of tropical lowland rain forests into oil palm and rubber plantations, PLoS ONE, 10, e0138077, https://doi.org/10.1371/journal.pone.0138077, 2015.

Schlesinger, W. H. and Bernhardt, E.: Biogeochemistry - an analysis of global change, 3 Edn., Academic Press, California, USA, 2013.

Schwendenmann, L. and Veldkamp, E.: The role of dissolved organic carbon, dissolved organic nitrogen and dissolved inorganic nitrogen in a tropical wet forest ecosystem, Ecosystems, 8, 339351, https://doi.org/10.1007/s10021-003-0088-1, 2005.

Silver, W. L., Neff, J., McGroddy, M., Veldkamp, E., Keller, M., and Cosme, R.: Effects of soil texture on belowground carbon and nutrient storage in a lowland Amazonian forest ecosystem, Ecosystems, 3, 193-209, https://doi.org/10.1007/s100210000019, 2000.

Sotta, E. D., Corre, M. D., and Veldkamp, E.: Differing N status and $\mathrm{N}$ retention processes of soils under old-growth lowland forest in Eastern Amazonia, Caxiuanã, Brazil, Soil Biol. Biochem., 40, 740-750, https://doi.org/10.1016/j.soilbio.2007.10.009, 2008.

Sundarambal, P., Balasubramanian, R., Tkalich, P., and He, J.: Impact of biomass burning on ocean water quality in Southeast Asia through atmospheric deposition: field observations, Atmos. Chem. Phys., 10, 11323-11336, https://doi.org/10.5194/acp-1011323-2010, 2010.

Suryatmojo, H., Fujimoto, M., Yamakawa, Y., Kosugi, K., and Mizuyama, T.: Water balance changes in the tropical rainforest with intensive forest management system, Int. J. Sustain. Future Hum. Secur., 1, 56-62, https://doi.org/10.1016/j.proenv.2015.07.039, 2013.
Tarigan, S. D., Sunarti, Wiegand, K., Dislich, C., Slamet, B., Heinonen, J., and Meyer, K.: Mitigation options for improving the ecosystem function of water flow regulation in a watershed with rapid expansion of oil palm plantations, Sustainability of Water Quality and Ecology, 8, 4-13, https://doi.org/10.1016/j.swaqe.2016.05.001, 2016.

Tung, P. G., Yusoff, M. K., Majid, N. M., Joo, G. K., and Huang, G. H.: Effect of $\mathrm{N}$ and $\mathrm{K}$ fertilizers on nutrient leaching and groundwater quality under mature oil palm in Sabah during the monsoon period, Am. J. Appl. Sci., 6, 1788-1799, https://doi.org/10.3844/ajassp.2009.1788.1799, 2009.

Van Breemen, N., Mulder, J., and Driscoll, C. T.: Acidification and alkalinization of soils, Plant Soil, 75, 283-308, https://doi.org/10.1007/BF02369968, 1983.

Van Genuchten, M. T.: A closed-form equation for predicting the hydraulic conductivity of unsaturated soils, Soil Sci. Soc. Am. J., 44, 892-898, https://doi.org/10.2136/sssaj1980.03615995004400050002x, 1980.

van Straaten, O., Corre, M. D., Wolf, K., Tchienkoua, M., Cuellar, E., Matthews, R. B., and Veldkamp, E.: Conversion of lowland tropical forests to tree cash-crop plantations loses up to half of stored soil organic carbon, P. Natl. Acad. Sci. USA, 112, 99569960, https://doi.org/10.1073/pnas.1504628112, 2015. 